\title{
Holocene climate change, vegetation history and human impact in the Central Mediterranean: evidence from the Maltese Islands
}

\author{
Francis A. Carroll ${ }^{\mathrm{a}}$, Chris O. Hunt ${ }^{\mathrm{a}, *}$, Patrick J. Schembri $^{\mathrm{b}}$, Anthony Bonanno $^{\mathrm{c}}$ \\ ${ }^{a}$ School of Geography, Archaeology E Palaeoecology, Queen's University Belfast, Belfast BT7 1NN, UK \\ ${ }^{\mathrm{b}}$ Department of Biology, University of Malta, Msida MSD 2080, Malta

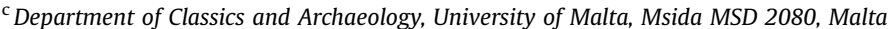

\section{A R T I C L E I N F O}

\section{Article history:}

Received 17 February 2012

Received in revised form

6 July 2012

Accepted 16 July 2012

Available online 27 August 2012

\section{Keywords:}

Malta

Holocene

Central Mediterranean

Palynology

Landscape degradation

Human impact

\begin{abstract}
A B S T R A C T
Holocene climates and human impact in the Mediterranean basin have received much attention, but the Maltese Islands in the Central Mediterranean, although a pivotal area, have been little researched. Here, sedimentary and palynological data are presented for three cores from the Holocene coastal and shallowmarine deposits of the Maltese Islands. These show deforestation from Pinus-Cupressaceae woodland in the early Neolithic, and then a long, but relatively stable history of agriculturally degraded environments to the present day. The major climate events which have affected the Italian and Balkan peninsulas to the north, and Tunisia to the south, are not reflected in the pollen diagrams from the Maltese Islands because of the strong anthropogenic imprint on the Maltese vegetation from early in the Neolithic. Previous suggestions of environmentally-driven agricultural collapse at the end of the Neolithic appear, however, to be substantiated and may be linked to regional aridification around $4300 \mathrm{cal}$. BP. Depopulation in early Medieval times is not supported by the current palynological evidence.
\end{abstract}

(c) 2012 Published by Elsevier Ltd.

\section{Introduction}

The Mediterranean has had a dynamic climate history, not least during the Holocene, where two dominant circulation patterns driven in the shorter timescale by the North Atlantic Oscillation (Roberts et al., 2004, 2011a, 2011b) and in the longer by changes in the monsoonal circulation (COHMAP Members 1988) have led to complex 'see-saw' relationships on a variety of timescales. The circulation patterns alternate to bring drought to Spain and the southern Levant and high rainfall to Morocco and the northern Levant, or high rainfall to Spain and the southern Levant and drought to Morocco and the northern Levant (Hunt et al., 2007). The Central Mediterranean, a pivotal area for these changing climatic regimes, is, however, rather complex, with Sicily having a different climatic history from Central Italy, to the North, or Tunisia, to the South (Ben Tiba and Rielle, 1982; Magri, 1999; Magri and Sadori, 1999; Sadori and Narcisi, 2001; Sadori et al., 2011). The climate history of the Maltese Islands, between Sicily and Tunisia, is

\footnotetext{
* Corresponding author. Tel.: +44 2890975147.

E-mail address: c.hunt@qub.ac.uk (C.O. Hunt).
}

thus of interest in resolving the complexity of Holocene climate in the Mediterranean basin.

From 8200 to 4000 BP, Tunisia, Northern Libya and the Western Desert in Egypt had a general, most probably stepwise, decline in humidity which is argued to have led to the degradation of much of a former vegetation cover (Gilbertson and Hunt, 1996; Kuper and Kropelin, 2006; Watrin et al., 2009), although Mercuri (2008a, 2008b) suggests that human impact was also an important factor. Superimposed upon this trend and continuing into the Late Holocene are significant but short episodes of desiccation, for instance at ca $8200,6200,4800,4100,3300$ and 550 and 350 cal. BP (e.g. Ouda et al., 1998; Hunt et al., 2001, 2011a, 2011b; Zielhofer et al., 2002, 2004, 2008; Marquer et al., 2008). Forest remained until the Greek period in the Gebel Akhdar in NE Libya (Hunt et al., 2002), but was eliminated by grazers and a climate change to more arid conditions in the Neolithic in NW Libya (Gilbertson and Hunt, 1996). In northern Tunisia forest degradation was suggested much later at around 400 cal. BP (Faust et al., 2004) although it is possible that this later date reflects lack of data.

In Italy, there was early- to mid-Holocene forest vegetation, which a growing consensus (e.g. Hunt, 1995; Watts et al., 1996; Magri, 1999; Ramrath et al., 2000; Magny et al., 2002; DrescherSchneider et al., 2007; Mercuri et al., 2011) suggests was affected 
in composition by climate change, with major aridification events leading to the decline of deciduous forest and the rise of the current sclerophyll woodlands. In Sicily, there has been discussion about whether the Early Holocene was dry or humid, with Tinner et al. (2009) suggesting that the very early Holocene was relatively dry and Sadori and Narcisi (2001), Frisia et al. (2006), Sadori et al. (2011) and Magny et al. (2011) presenting evidence of humidity. The very early Holocene in SW Sicily at low altitudes was marked by relatively open Pistacia scrub (Tinner et al., 2009) with Olea woodland expanding at 8400 cal. BP, then contracting at 8200 cal. BP, followed by expansion of Quercus ilex-dominated woodland around 7000 cal. BP suggesting increased relative humidity. Forests persisted until Greek and Roman colonists disrupted the vegetation in the 1st millennium BC (Noti et al., 2009; Tinner et al., 2009; Magny et al., 2011). The drier coastal lowland site at Biviere di Gela in SE Sicily was afforested with deciduous trees after 7200 cal. BP, with Juniperus expanding ca 6900 cal. BP, possibly as the result of fires. Following the juniper peak, $Q$. ilex and Olea woodland and Pistacia scrubland expanded after 6600 cal. BP, probably as the result of increasing humidity. Forest vegetation was reduced by fire during the Neolithic, with major disruption of vegetation following the Greek colonisation (Noti et al., 2009). At higher altitude at Lago Pergusa, the Early Holocene was marked by deciduous oak woodland, suggesting a relatively humid environment. Evergreen oaks become more common and Olea and Pistacia also start to expand after $8200 \mathrm{cal}$. BP. An opening of vegetation ca 4000 cal. BP suggests aridification (Sadori and Narcisi, 2001; Sadori et al., 2008, 2011). Overall, in Sicily, the records suggest a relatively humid Early Holocene, with desiccation during the $8.2 \mathrm{ka}$ event but high effective humidity until around 7500 cal. BP, with episodes with winter drought between 7500 and $6500 \mathrm{cal}$. BP, with reducing rainfall around $6000 \mathrm{cal}$. BP and further progressive drying after 4000 cal. BP (Sadori and Narcisi, 2001; Frisia et al., 2006; Noti et al., 2009; Tinner et al., 2009; Magny et al., 2011; Sadori et al., 2011).

The mid-Holocene deforestation of Southern Spain, Italy, Sicily and Greece is, however, mostly the result of the spread of farming and other anthropogenic activity (e.g. Sadori and Narcisi, 2001; Mercuri et al., 2011; Sadori et al., 2011) and becomes marked in many areas only after $4000 \mathrm{cal}$. BP. The situation on the Maltese

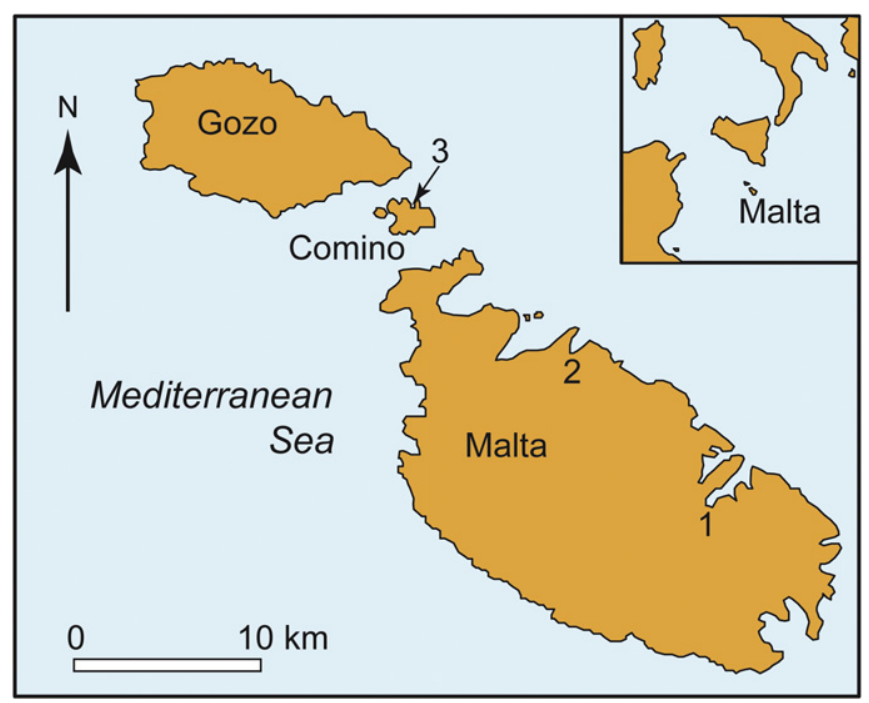

Fig. 1. The Maltese islands, showing their place in the central Mediterranean (inset). The coring sites are numbered. 1 = Msida, 2 = Salina Bay =2, and $3=$ Santa Marija Bay, Comino.
Islands, in the centre of the Mediterranean (Fig. 1), is currently virtually unknown, but recent archaeological work (Malone and Stoddart, 2009) suggests that environmental controls and in particular aridification events may have led to major events in human history and particularly to the end of the highly distinctive and archaeologically-significant Maltese Temple Culture.

The impact of people on the Maltese landscape, from Neolithic to modern times, is reputed to have been severe (Schembri, 1997) and the present population density is one of the highest in the world at over 1307 per $\mathrm{km}^{2}$ (National Statistics Office, 2010). The islands' natural environment, mostly developed on karstic limestone (Cassar et al., 2008), is certainly highly degraded. Schembri (1997) describes the main vegetation cover as 'maquis, garrigue and steppe with some woodland, coastal wetlands and sand dunes'. Elsewhere in the Mediterranean maquis and garrigue are regarded as degraded remainders of woodland (e.g. White, 2000; Grove and Rackham, 2001). Maltese soils have been subjected to adverse anthropogenic activities including translocation, infilling of disused quarries, landscaping of new sites, illegal dumping, maintenance of terracing, creation of 'made ground', replacement of eroded or shallow soils and urbanization (Vella, 2001; MEPA, 2006). Consequently, researchers have been inhibited from attempting to reconstruct the past environment of the Maltese Islands because of the problem of identifying locations where undisturbed sediment would enable accurate determination of previous conditions. One type of locality considered suitable, however, is the coastal alluvial plains (e.g. Marriner et al., 2012) and this paper explores their potential for palaeoenvironmental work. In this paper we describe the findings of stratigraphical and palynological investigations of coastal alluvial plains and use them to assess climate change, reconstruct vegetation history and evaluate the impact of humans during the middle to late Holocene in the Maltese Islands.

\section{The Maltese Islands}

A number of authors, including Trechmann (1938), Paskoff and Sanlaville (1978), Bosence et al. (1981), Schembri (1995, 1997), Pedley et al. (2002) and Schembri et al. (2009) have described in varying degrees of detail the physical characteristics of the Maltese Archipelago. The Maltese Islands (Fig. 1) are highly isolated and very small, covering only some $316 \mathrm{~km}^{2}$ in total. Geologically, they consist of interbedded limestones and clays of Oligocene to basal Miocene age (Pedley et al., 2002). Biogeographically and from reconstruction of Quaternary environments, Hunt and Schembri (1999) and Hunt (1997) consider the Islands during the Quaternary to have been forested during warm stages and denuded of vegetation during cold stages.

The archaeology of the Maltese Islands extends back into the Neolithic. Archaeological investigation has focused on more than thirty ancient temples and the cave fill at Ghar Dalam, but there is remarkably little surviving evidence for early domestic sites or palaeoeconomy (Malone and Stoddart, 2009: 349-350). The earliest archaeological evidence for activity in the Islands relates to the Neolithic Ghar Dalam phase, dated to ca 7000-6500 cal. BP (Trump, 1995-1996; Malone et al., 2009: 342). Prior to this phase there appears to be no firm archaeological evidence for human presence (Trump, 2002). By ca 5500 cal. BP, the Maltese Temple Period had started, with the building of some of the earliest largescale structures in the world by what appears to have been a relatively isolated island Neolithic civilisation. This persisted for about 1200 years, ending ca 4300 cal. BP (Malone et al., 2009: 342-346). It has been suggested that the end of the Temple Period may relate to drought or environmental degradation (Malone and Stoddart, 2009: 383-384). 
By about 4000 cal. BP the first Bronze Age culture, the Tarxien Cemetery phase, had reached the islands (Malone et al., 2009: 342346). Thereafter, the Maltese Islands have had a relatively normal Central Mediterranean history, with a local Iron Age, and then occupation by waves of invaders including the Phoenicians, Romans, Arabs, Normans, Aragonese, Knights Hospitallers, French and British (Blouet, 1997; Bonanno, 2003, 2005).

A hiatus in occupation may, however, have occurred during the Arab Period (870-1090 AD). Corroboration for this population break comes from the writings of al-Himyari (Brincat, 1995) who reported that Malta was virtually uninhabited for most of the 180 year Arabic period. This account seems to be corroborated by the writings of ibn Hawqal, whose final and definitive edition is dated $988 \mathrm{AD}$, contemporary with the period in question (Wettinger, 2011). This view is supported by an apparent lack of linguistic substratum (language that influences another one while that second language supplants it) and a lack of archaeological evidence. Brincat (1995) is of the opinion that the only reason for such a linguistic deficiency is a 'sudden and crushing intrusion' such as the violent Arabic invasion in $870 \mathrm{AD}$. He suggests that any population left on the islands would eventually have been absorbed into the Arabic speaking community of some 5000 persons that are known to have occupied the islands in 1048-1049. Furthermore, whatever language they spoke would also have been eliminated as Arabic became the language of choice.

Within the Maltese Islands, current understanding of palaeoenvironments is largely derived from studies of Middle to Late Pleistocene slope deposits, loess, palaeosoils and tufas and from environmental work done on mid-Holocene and later archaeological sites. Environmental reconstruction from Quaternary deposits suggests that at times during the Late Pleistocene the landscape was extremely open, with deposition of loess, colluvium and braided alluvial sediments. Palaeosoils and tufas suggest episodes of interglacial or interstadial status, characterized by substantial scrub or forest vegetation (Hunt, 1997). The Holocene vegetation of the islands before the first archaeological sites is, however, unknown, although biogeographical reconstructions suggest an early Holocene sclerophyll oak-pine forest cover (e.g. Schembri and Lanfranco, 1993). Mollusc analysis in the Neolithic Xaghra (Brocktorff) Circle suggests that the landscape around the site was already very open in the earliest phases, probably around $6000 \mathrm{cal}$. BP, and that it remained so through the Neolithic and Bronze Age (Schembri et al., 2009). An Early Neolithic landscape (ca 73005600 cal. BP), dominated by pistachio scrub with areas of open grazed land and with upper estuarine coastal marsh, is reported in outline from boreholes at Burmarrad by Marriner et al. (2012). Trump (1966) reported charcoal from Skorba that included Cercis siliquastrum, Crataegus and Fraxinus in the early Neolithic and Olea europaea (according to the analyst possibly cultivated Olive) in the later Neolithic. A Bronze-Age pollen assemblage of open aspect, but with some pine and olive, was recorded from a cistern-fill by Godwin (1961) and Evans (1971). Hunt (2000) described an openground pollen assemblage from what is now known to have been a Punic or Hellenistic pit-fill at Tas-Silg and recently (Hunt, in press) a discontinuous sequence of pollen assemblages from the site. The assemblages, which all show a level of taphonomic bias consistent with the depositional environment, commence early in the Tarxien phase (probably ca 5000 cal. BP) with spectra indicating open steppic landscapes with cereal cultivation and scrub/woodland characterized by Pinus, Juniperus, Pistacia and Cistus. Later Tarxien and later prehistoric assemblages suggest open steppic landscapes with cereal cultivation, with significant aridification and land degradation suggested by later Bronze Age and Punic-Classical Period herb assemblages. Post-Medieval landscapes were described by Hunt and Vella (2004-2005), who reported 19th Century AD pollen from a field-fill at Mistra Valley, which points to an open agricultural landscape with the cultivation of cotton. Finally, Fenech (2009) reported a preliminary version of a pollen diagram from a deep borehole at Marsa, which is described in more detail and with further radiocarbon dates below.

\section{The cores}

Three cores were obtained (Tables 1, S1-S3, Fig. 1). All were very close to sea level, but their elevations given in Table 1 are derived from Maltese Mapping Agency maps. Two were on the main island of Malta. The third location was on Comino Island. No suitable coring sites could be located on the island of Gozo.

The Marsa core was taken at the Marsa Sports Ground, near the entrance, on former marshland reclaimed from the Grand Harbour under British rule in the 1860s. The Grand Harbour has the largest catchment in the Maltese Islands, draining much of the southern end of the Island of Malta, including an extensive limestone plateau. The catchment was intensively farmed from the 17th Century, but now much of it has become urbanized with the spread of the Valetta conurbation. The low-lying ground around the Sports Ground still floods as the result of the largest winter rainstorms, but there is no perennial river today. In the past, freshwater springs were present at the upslope edge of the Marsa Valley alluvial fill, but these no longer run as the result of the drawing down of the island's main sea-level aquifer. During excavations on the edge of the Grand Harbour some $200 \mathrm{~m}$ to the East of the core site in 2009, $\mathrm{COH}$ saw parts of a Roman wharf complex, close to present-day sealevel.

The stratigraphy of this core is described in Table S1. The borehole passed through 19th century made ground, which is known from historical records to have been emplaced in 1867, then through estuarine muds, then fluvial gravels before reaching bedrock.

The Salina Bay Core was taken at Salina Bay alongside a dredged channel draining the Burmarrad valley on recently prograded estuarine sediments. The Burmarrad valley is one of the most extensive and fertile agricultural valleys in Malta, a graben which extends deep into the interior of the island and with a valley-head close to the ancient capital, Mdina. A small near-perennial stream discharges into the dredged channel which runs by the coring site. Today, the bay downstream from the coring site is constricted by a series of saltpans of 17 th Century, or probably earlier, origin. One of the few wooded areas on the island, the Kennedy Grove, a plantation of Aleppo pines, olive, evergreen oak, oleander, acacia, tamarisk and eucalyptus first planted in 1964 (Borg, 1990) lies immediately upstream of the coring site. Some $400 \mathrm{~m}$ upstream from the coring site, part of a Roman wall has been located. There is historical and archaeological documentation of the use of Salina

Table 1

Location and details of the boreholes used in this study.

\begin{tabular}{|c|c|c|c|c|c|c|}
\hline Name of site & Northing & Easting & Depth of borehole (m) & Elevation (m) & To bedrock & Coring \\
\hline Marsa Sports Ground, Malta & $35^{\circ} 52^{\prime} 35.9^{\prime \prime}$ & $14^{\circ} 25^{\prime} 14.78^{\prime \prime}$ & 12.15 & 5.1 & Yes & Commercial Percussion Auger \\
\hline Salina Bay, Malta & $35^{\circ} 56^{\prime} 39.84^{\prime \prime}$ & $14^{\circ} 25^{\prime} 14.78^{\prime \prime}$ & 8.96 & 6.9 & No & Modified Livingstone \\
\hline Santa Marija Bay, Comino & $36^{\circ} 00^{\prime} 56.98^{\prime \prime}$ & $14^{\circ} 20^{\prime} 13.18^{\prime \prime}$ & 2.71 & 5.7 & Yes & Modified Livingstone \\
\hline
\end{tabular}


Bay and its inland extension as an active harbour, certainly from Roman times and perhaps before then (e.g. Bowen-Jones and Beeley, 1960; Blouet, 1964, 1997; Bonanno, 2005; Marriner et al., 2012).

The stratigraphy of the Salina Bay core is shown in Table S2. The core penetrated over half a metre of recent sea-grass debris which local informants told us had accumulated during recent storms. Below this layer, the core passed through estuarine and then shallow-marine sands.

The Comino Island core was taken in muddy alluvial/lagoonal sediments behind a low sandy coastal barrier in a seasonal lagoon (dry at time of sampling and in use as a campsite) at the head of Santa Marija Bay on Comino Island. Behind the dry lagoon, a shallow valley stretches into the interior of the island. A series of small fields, confined by dry-stone walls, can be found on the valley floor, but most of the island has virtually no soil cover, with extensive areas of bare limestone and steppe-garrigue vegetation in interstices in the rock. In the 17th Century a fort was built on the island by the Knights of St John. Before the French conquest, it apparently became a pirate lair. In the 19th Century the British Administration had a penal colony on the island. Today the island has a single permanent resident and several hundred summer visitors and hotel workers.

The stratigraphy of the Comino Island core is shown in Table S3. The core passed through silty lagoonal sediments, rather dry at the top, and encountered limestone bedrock at $2.71 \mathrm{~m}$.

\section{Sampling and analysis}

The cores were split and sampled at the Department of Biology, University of Malta. AMS radiocarbon dating was undertaken at Beta Analytic Inc. of Florida, USA and the 14Chrono Centre, Queen's University, Belfast. Granulometry was done using sedimentation, following standard methods (Gale and Hoare, 1991). In the gravelly lower part of the Marsa core, the granulometric analyses were done on the fine-grained interbeds between the gravel bodies. Magnetic susceptibility was done using standard methods, with measurements using a Bartington MS2b meter on air-dried material passing a $2 \mathrm{~mm}$ brass sieve (Gale and Hoare, 1991). Lead was determined semi-quantitatively using X-ray fluorescence in a Spectro-X-Lab instrument.

Palynology preparation followed a version of the Hunt (1985) method, with decalcification in hydrochloric acid, disaggregation in potassium hydroxide and sodium pyrophosphate, sieving on nylon mesh at $6 \mu \mathrm{m}$ to remove fines and solutes, and swirling on a clock-glass to remove silt and sand. The open gravelly sediment of the lower part of the Marsa core was seen to present particular dangers for the pollen analyst, especially given the prevalence of recycled and intrusive carbon as is shown by the radiocarbon dates (below). In an attempt to address this issue, pollen samples from the gravelly units were taken only from the most fine-grained and cohesive interbeds. Damaged and recycled (secondarily derived) pollen are shown in the pollen diagrams, but neither of these are included in the Pollen Sum. In some cases in the base and the top of the Marsa core, results of adjacent samples were combined within the diagram to improve the spectrum displayed, following practice advocated by Horowitz (1992). Palynological analyses included pollen, organic-walled microplankton and palynofacies (the whole organic particulate assemblage: Tyson, 1995; Hunt and Coles, 1988). Recycled pollen was identified by having abnormal preservation and this was confirmed by fluorescence microscopy (following Hunt et al., 2007). The palynofacies counts followed Tyson (1995) and Hunt and Coles (1988) with classes including marine microplankton, foraminiferal test linings, freshwater microplankton, pollen grains and plant debris, fungal debris and thermally mature.
(The term 'thermally mature' encompasses all organic matter other than material of fungal origin showing dark brown or black under the light microscope including microcharcoal, but also inert or semi-inert carbon particles, coal fragments and so on derived from bedrock, since these are not easily separated under light microscopy.)

\section{Radiocarbon dating}

Eleven radiocarbon dates were obtained from the Marsa core (Table 2). Cerastoderma shell at Marsa was calibrated using the algorithm for $50 \%$ marine carbon, since the high frequency of nonmarine algae in the core points to considerable freshwater input to the Grand Harbour at this point (below). It must be noted that radiocarbon dating in these high-energy alluvial and shallow marine sediments is not straightforward and that it is almost inevitable that much organic material and particularly charcoal is recycled. It is also highly likely that shell and charcoal fragments, especially in the rather loose gravelly lower part of the Marsa core, are intrusive as a result of the mechanical coring process. In the following discussion, it is tentatively suggested that the dates from $4.38-4.43 \mathrm{~m}, 6.28-6.33 \mathrm{~m}, 8.48-8.53 \mathrm{~m}$ and $10.58-10.63 \mathrm{~m}$ at Marsa are broadly coeval with the layers in which they were found. The uncertainty about dating in this core is so great that we do not regard it as appropriate to apply an age/depth model. The discontinuities in the pollen and lead records, particularly in the interval between zones M-D and M-H, are sufficient to suggest that deposition was episodically discontinuous.

Seven dates were obtained from the Salina Bay core (Table 2). Cerastoderma shell from this core was calibrated using the algorithm for $100 \%$ marine carbon, since this seems to have been an open marine environment (below). In this core, to assess possible old carbon effects, shell and wood were dated from the same sample at 8.49-8.54 $\mathrm{m}$ and shell and charcoal were dated from the same sample at $8.69-8.74 \mathrm{~m}$. In each level, the dates obtained from the different materials were extremely close. Most of the dates from the Salina Bay core are in stratigraphic order, but it is possible that the date on bulk sediment at $2.34-2.44 \mathrm{~m}$ contains 'old' carbon, since a shell date lower in the core at $3.14-3.19 \mathrm{~m}$ is younger. Chronological modelling was performed on this core using clam software (Blaauw, 2010) and results are shown in Fig. S1.

Two dates were obtained from the Comino Island core (Table 2). In this core, the dates are in stratigraphical order, but it is possible that there are one or more stratigraphic discontinuities in this core.

The relatively small numbers of dates from each core, and the presence at Marsa of recycled and intrusive carbon, together with the strong possibility of discontinuities in deposition, were deemed to preclude reliable age/depth modelling there and at Comino. Available reliable calibrated dates are, however, shown on Figs. 2-10.

\section{Sediment analysis}

The results of sediment analysis are shown in Figs. 2-4. In the Marsa core (Fig. 2), the finer interbeds within the basal gravels generally contain over $40 \%$ clay. Between 10.18 and $8.58 \mathrm{~m}$ the sediments are sand-dominated. The deposits between 8.58 and $3.43 \mathrm{~m}$ typically contain over $40 \%$ clay and on inspection showed cyclic fining-up sequences up to $2 \mathrm{~m}$ thick which are reflected in the granulometry. It is likely that the largest fining-upward sequences took several centuries to form. From 3.43 to $2.18 \mathrm{~m}$ the sediments are very sandy, while between 2.18 and $0.72 \mathrm{~m}$ the sediments are silty sands and sandy silts with comparatively little clay. 
Table 2

Radiocarbon dates from the cores.

\begin{tabular}{|c|c|c|c|c|c|c|c|}
\hline $\begin{array}{l}\text { Core and } \\
\text { sample no. }\end{array}$ & Depth (m) & Lab code & Material & Radiocarbon age & $\begin{array}{l}2 \sigma \text { calibrated date range } \\
\mathrm{BP} \text { (probability) }\end{array}$ & $\begin{array}{l}2 \sigma \text { calibrated date } \\
\text { range } \mathrm{AD} / \mathrm{BC}\end{array}$ & $\begin{array}{l}\text { Calibration } \\
\text { (\% marine) }\end{array}$ \\
\hline Marsa 7 & $1.68-1.73$ & Beta-208958 & Indet. charcoal & $106.8 \pm 0.4 \mathrm{pMC}$ & & & $\mathrm{n} / \mathrm{a}$ \\
\hline Marsa 58 & $4.38-4.43$ & Beta-208961 & Indet. charcoal & $1460 \pm 40 \mathrm{BP}$ & $1296-1410$ & AD 540-654 & INTCAL09 \\
\hline Marsa 90 & $6.28-6.33$ & Beta-200517 & Indet. charcoal & $2510 \pm 40 \mathrm{bp}$ & $\begin{array}{l}2370-2386(0.012774) \\
2458-2743(0.987226)\end{array}$ & $\begin{array}{l}\text { BC } 794-509 \text { and } \\
\text { BC } 437-421\end{array}$ & INTCAL09 \\
\hline Marsa 108 & $7.63-7.68$ & Beta-208960 & Plant fragments & $107.3 \pm 0.4 \mathrm{pMC}$ & & & $\mathrm{n} / \mathrm{a}$ \\
\hline Marsa 120 & $8.48-8.53$ & Beta-200518 & Indet. charcoal & $5730 \pm 40 \mathrm{bp}$ & $\begin{array}{l}6414-6419(0.00782) \\
6424-6425(0.002954) \\
6436-6637(0.989235)\end{array}$ & $\begin{array}{l}\text { BC } 4688-4487 \text { and } \\
4476-4475 \text { and } \\
4470-4465\end{array}$ & INTCAL09 \\
\hline Marsa 149 & $9.93-9.98$ & Beta-203318 & Bulk sediment & $19,530 \pm 90 \mathrm{bp}$ & $\begin{array}{l}22,718-22,779(0.014688) \\
22,938-23,677(0.985312)\end{array}$ & $\begin{array}{l}\text { BC } 21,728-20,989 \\
\text { and } 20,830-20,769\end{array}$ & $\mathrm{n} / \mathrm{a}$ \\
\hline Marsa 162 & $10.58-10.63$ & Beta-200519 & Seeds & $5870 \pm 40 \mathrm{bp}$ & $\begin{array}{l}6567-6588(0.031803) \\
6603-6610(0.007539) \\
6616-6788(0.960658)\end{array}$ & $\begin{array}{l}\text { BC } 4839-4667 \text { and } \\
4661-4654 \text { and } \\
4639-4618\end{array}$ & INTCAL09 \\
\hline Marsa 186 & $11.78-11.83$ & Beta-208959 & c.f. Cupressus sp. leaf & $>44,000 \mathrm{bp}$ & & & $\mathrm{n} / \mathrm{a}$ \\
\hline Marsa 187 & $11.83-11.88$ & UB-10246 & Cerastoderma sp. shell & $5130 \pm 37$ bp & $5579-5736(1)$ & BC $3787-3630$ & Marine09 (50\%) \\
\hline Marsa 189 & $11.93-11.98$ & UB-10246 & Cerastoderma sp. shell & $4589 \pm 37 \mathrm{bp}$ & $\begin{array}{l}4838-5703(0.977705) \\
5107-5121(0.008323) \\
5189-5211(0.013972)\end{array}$ & $\begin{array}{l}\text { BC } 3262-3240 \text { and } \\
3172-3158 \text { and } \\
3124-2889\end{array}$ & Marine09 (50\%) \\
\hline Marsa 193 & $12.13-12.18$ & Beta-203320 & Bulk sediment & $20,020 \pm 90 \mathrm{bp}$ & $23,534-24,298(1)$ & BC $22,349-21,585$ & $\mathrm{n} / \mathrm{a}$ \\
\hline Salina 34 & $2.34-2.44$ & UB-7060 & Bulk sediment & $3664 \pm 36$ bp & $\begin{array}{l}3889-4090(0.99537) \\
4133-4137(0.00427)\end{array}$ & $\begin{array}{l}\text { BC } 2188-2184 \text { and } \\
2141-1940\end{array}$ & INTCAL09 \\
\hline Salina 50 & $3.14-3.19$ & UBA-10258 & Cerastoderma sp. Shell & $3850 \pm 21 \mathrm{bp}$ & $3559-3864(1)$ & BC $1915-1610$ & Marine09 (100\%) \\
\hline Salina 157A & $8.49-8.54$ & UBA-10252 & Cerastoderma sp. Shell & $6149 \pm 24 \mathrm{bp}$ & $6360-6643(1)$ & BC $4694-4411$ & Marine09 (100\%) \\
\hline Salina 157B & $8.49-8.54$ & UBA-10253 & Charcoal & $5809 \pm 38 \mathrm{bp}$ & $\begin{array}{l}6497-6678(0.955704) \\
6683-6693(0.015039) \\
6702-6718(0.029256)\end{array}$ & $\begin{array}{l}\text { BC } 4769-4753 \text { and } \\
4744-4734 \text { and } \\
4729-4548\end{array}$ & INTCAL09 \\
\hline Salina $161 \mathrm{~A}$ & $8.69-8.74$ & UBA-10251 & Shell & $6316 \pm 47 \mathrm{bp}$ & $6511-6844(1)$ & BC $4925-4562$ & Marine09 (100\%) \\
\hline Salina 161B & $8.69-8.74$ & UBA-10250 & Wood & $5740 \pm 26 \mathrm{bp}$ & $\begin{array}{l}6455-6456(0.003924) \\
6466-6634(0.996076)\end{array}$ & $\begin{array}{l}\text { BC } 4685-4517 \text { and } \\
4507-4506\end{array}$ & INTCAL09 \\
\hline Salina 166 & $8.94-8.96$ & UB-6989 & Bulk sediment & $6154 \pm 42 \mathrm{bp}$ & $6939-7167(1)$ & ВC 5218-4990 & INTCAL09 \\
\hline Comino 47 & $2.40-2.45$ & UBA-10248 & Plant macrofossils & $774 \pm 33 \mathrm{bp}$ & $659-729(1)$ & AD 1221-1291 & INTCAL09 \\
\hline Comino 50 & $2.55-2.60$ & UBA-10249 & Plant macrofossils & $1955 \pm 43 b p$ & $1820-1996(1)$ & BC 47-AD 130 & INTCAL09 \\
\hline
\end{tabular}

\section{Marsa, Malta}

Sediments

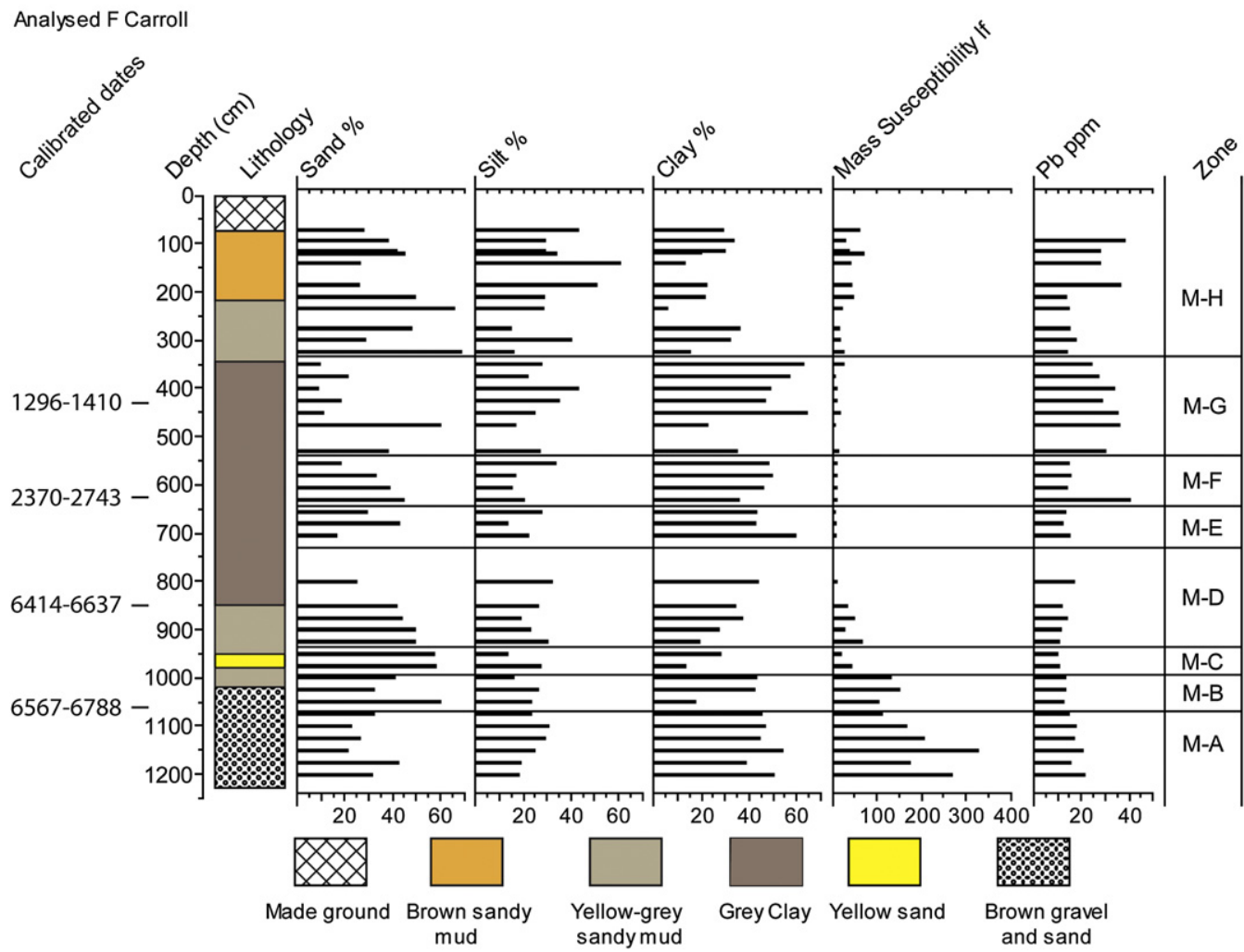

Fig. 2. The granulometric, low frequency mass susceptibility and lead results from the Marsa core. 


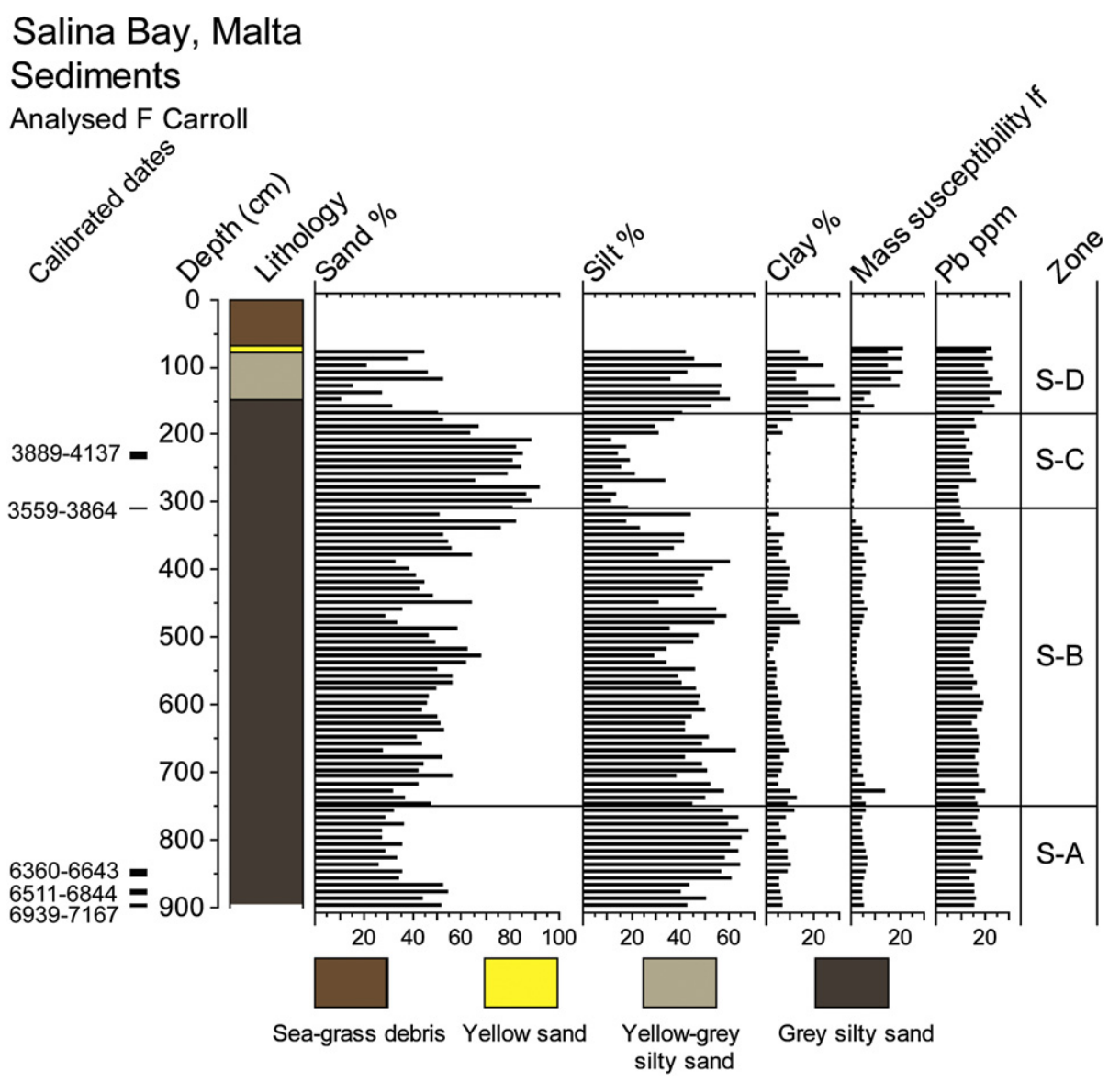

Fig. 3. The granulometric, low frequency mass susceptibility and lead results from the Salina Bay core.

In the Salina Bay core (Fig. 3), the sediments are relatively wellsorted sandy silts and silty sands. There is a general coarseningupward sequence between $8.5 \mathrm{~m}$ and $2.1 \mathrm{~m}$, but superimposed on this trend are several marked fining-upward sequences. Above $2.1 \mathrm{~m}$ the sediments become sandy clayey silts.

A similar pattern is shown by the Comino Island core (Fig. 4), with a basal section of relatively clean sandy silts and silty sands with a series of fining-up and coarsening up sequences. Above $0.83 \mathrm{~m}$, the sediments become sandy clayey silts.

\section{Magnetic susceptibility}

In the Marsa core (Fig. 2), magnetic susceptibility values are extremely high in the basal sections, with several low frequency determinations over 200 SI units. This is particularly the case in the basal gravels, but values remain raised until the start of claydominated sedimentation at $8.58 \mathrm{~m}$. Values then are generally low until the clay-dominated sedimentation ends at $3.43 \mathrm{~m}$, after which values rise gently to about 40 SI units.

In the Salina Bay core (Fig. 3), mass susceptibility values are low but relatively uniform around 5 SI units from the base of the core to about $3.5 \mathrm{~m}$, where values fall. A rise in mass susceptibility values occurs from about $2.0 \mathrm{~m}$, reaching values of 15-20 SI units at $1.5 \mathrm{~m}$.

Magnetic susceptibility figures for the Comino Island core (Fig. 4) are generally low, with low frequency mass susceptibility showing a small peak around $2.60 \mathrm{~m}$, then falling to very low values until a slight rise at $1.30-1.10 \mathrm{~m}$. A major rise in mass susceptibility occurs at $0.70 \mathrm{~m}$ and values then remain high to the top of the core.

\section{Lead}

In the Marsa core (Fig. 2), lead values are around 20-15 ppm from the base of the core to $5.4 \mathrm{~m}$, with one isolated high value at $6.40 \mathrm{~m}$. Between 5.4 and $3.34 \mathrm{~m}$ there is a peak in lead, with values of about $40 \mathrm{ppm}$. Low values are then present until a sudden rise at $1.8 \mathrm{~m}$, with high values to the top of the analysed section.

Lead values in the Salina Bay core (Fig. 3) remain remarkably uniform around 15-20 ppm through most of the core. From about $1.5 \mathrm{~m}$ the lead values rise to around $25 \mathrm{ppm}$. A similar pattern, with fairly steady values of about $20 \mathrm{ppm}$ is shown by the Comino Island core (Fig. 4), although there is a small peak with values of around $38 \mathrm{ppm}$ between 2.6 and $2.3 \mathrm{~m}$, a further, lower peak between 1.7 and $1.3 \mathrm{~m}$ and a sharp rise to around $40 \mathrm{ppm}$ at $0.7 \mathrm{~m}$.

\section{Pollen analysis}

Results of the palynological analysis of the Marsa core are shown in Figs. 5 and 6 and summarized in Table S4. Eight pollen zones (M-A to $\mathrm{M}-\mathrm{H}$ ) are recognized. In the basal sections of the core (pollen zone M-A) assemblages are dominated by Pinus, with percentages of $55-82 \%$. Also important in this zone is Juniperus/ Tetraclinis. The pollen of the two taxa is very similar morphologically, separated only by the size of the ornament, which is larger in Tetraclinis. Measurement of the ornament of specimens in this basal unit shows size distributions comparable to that of modern Tetraclinis, but the possibility cannot be excluded that some Juniperus specimens are also present. Some herbaceous taxa - predominantly Artemisia, Plantago, Chenopodiaceae, Lactucae, Poaceae - 


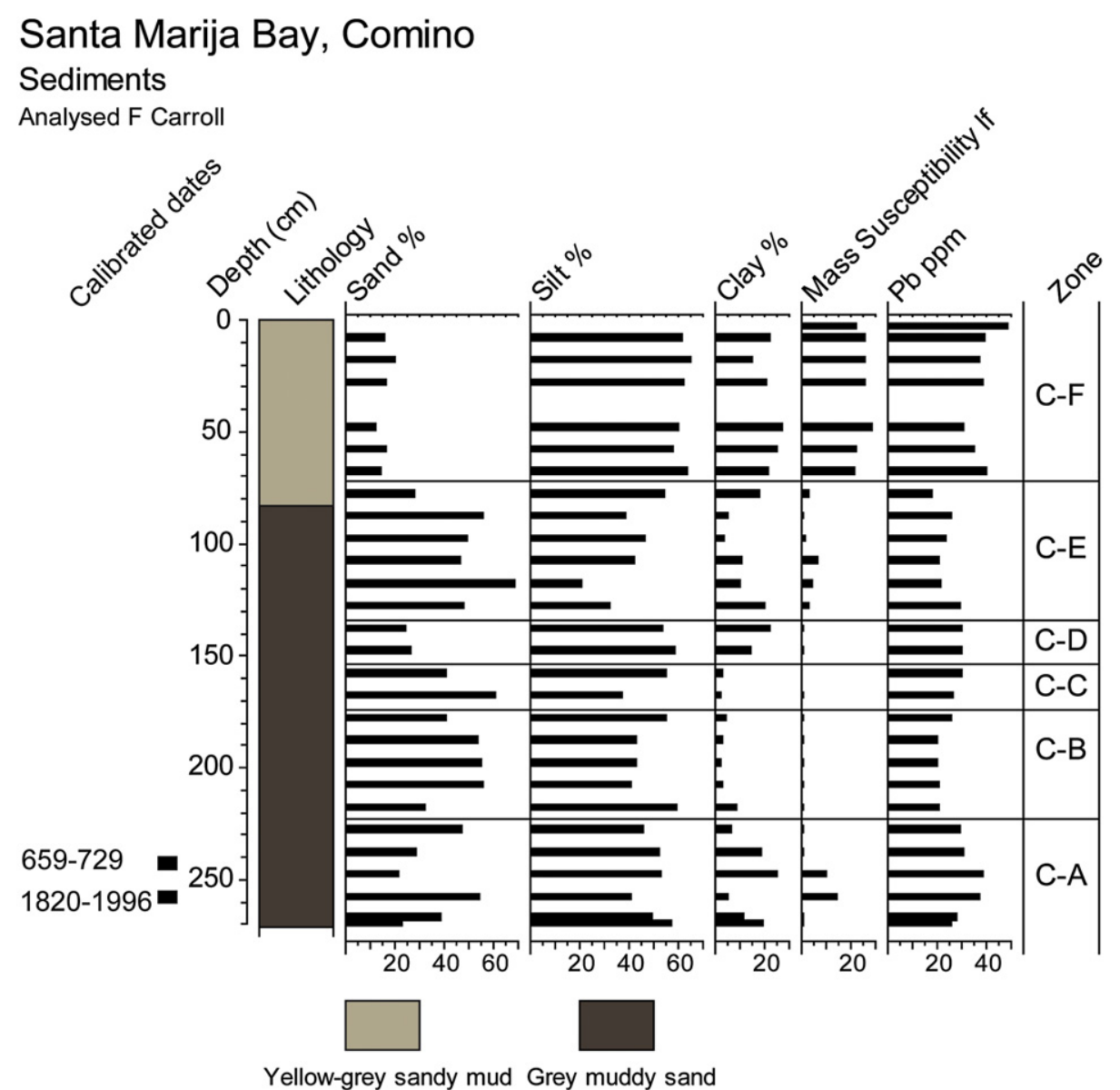

Fig. 4. The granulometric, low frequency mass susceptibility and lead results from the Comino Island core.

are also present and Cereal-type pollen appears in one sample. Freshwater microplankton is intermittently present and the palynofacies is heavily dominated $(42-94 \%)$ by thermally mature material, which includes microcharcoal, some burnt cuticles and some subangular black carbon of possible geological origin.

Above this level, Pinus and Tetraclinis/Juniperus decline through zones M-B to M-E, while several herbaceous taxa, principally Poaceae, Plantago, Lactucae, Cyperaceae, start to rise in M-B and peak in M-E, declining thereafter. A further group of herbaceous taxa, including Artemisia, Brassicaceae, Caryophyllaceae, Chenopodiaceae, starts to rise in or after $M-B$, but remain high until the end of M-G. Cereal pollen is well-represented, with around $10 \%$ in many samples between M-B and M-F and lower values for the rest of the core. Olea shows a similar pattern, but with lower values. In zones M-B to M-E, freshwater microplankton is common and marine dinoflagellate cysts, algae and foraminiferal test linings are consistently present although in low percentages. Dinoflagellate cysts such as Spiniferites mirabilis and Operculodinium centrocarpum are the most common marine taxa in zones M-B to M-E. Thermally mature matter remains very high in zones M-B to M-D and VAMs (vesicular arbuscular micorrhyzeae: fungal microfossils of root symbiotes) are extremely common in these zones.

Zone M-G shows high Caryophyllaceae, Chenopodiaceae and Artemisia, the presence of Agrostemma and Silene, and rising Lactucae and Spergula-type. Lactucae and Spergula type dominate M$\mathrm{H}$, but at the top of this zone Poaceae, Plantago and Pinus rise. In zones $\mathrm{M}-\mathrm{F}$ and $\mathrm{M}-\mathrm{G}$ foraminifer test linings and Palambages sp. predominate amongst the marine microfossils, while in $\mathrm{M}-\mathrm{H}$ freshwater and marine microfossil assemblages are extremely variable and usually dominated by only one or two species. Thermally mature material rises fairly steadily from a low at the base of $\mathrm{M}-\mathrm{G}$ and VAMs also rise in $\mathrm{M}-\mathrm{G}$ and $\mathrm{M}-\mathrm{H}$.

Palynology from the Salina Bay core is shown in Figs. 7 and 8 and summarized in Table S5. Four zones were recognized. The basal zone (S-A) is characterized by abundant (around 20\%) Poaceae, Plantago and Lactucae; lesser (about 5\%) Pinus, Rosaceae, Asteraceae, Urtica, Cerealia and low counts of Quercus (mostly deciduous type), Artemisia, Asphodelus, Cyperaceae, Ranunculus, Serratula type and Typha. Foraminifer test linings are common and the marine dinoflagellate cysts assemblages are dominated by Spiniferites mirabilis. There are low percentages of freshwater microplankton. The palynofacies is dominated by plant cell walls, probably mostly derived from sea-grass, since there is little plant cuticle.

Zone S-B is essentially similar, but with lowered percentages of Plantago, raised Cerealia and Chenopodiaceae. Foraminifer test linings decline gently. Both marine and freshwater microplankton assemblages are more variable and often dominated by a single species.

Zone S-C is characterized by $20 \%$ or more of Polypodium, raised (about 15\%) Plantago, and lowered Rosaceae, Asteraceae, Chenopodiaceae, Poaceae, Serratula type, Urtica and Cerealia. Marine microplankton is virtually absent, but freshwater assemblages are dominated by Psilate algal cysts and Sigmopollis sp.

Most taxa decline sharply in zone S-D, but Pinus rises to over $70 \%$. Microplankton assemblages are monospecific or absent and thermally mature material dominates the palynofacies.

The palynology of the Comino Island core is shown in Figs. 9 and 10 and summarized in Table S6. Six zones were recognized, but this 

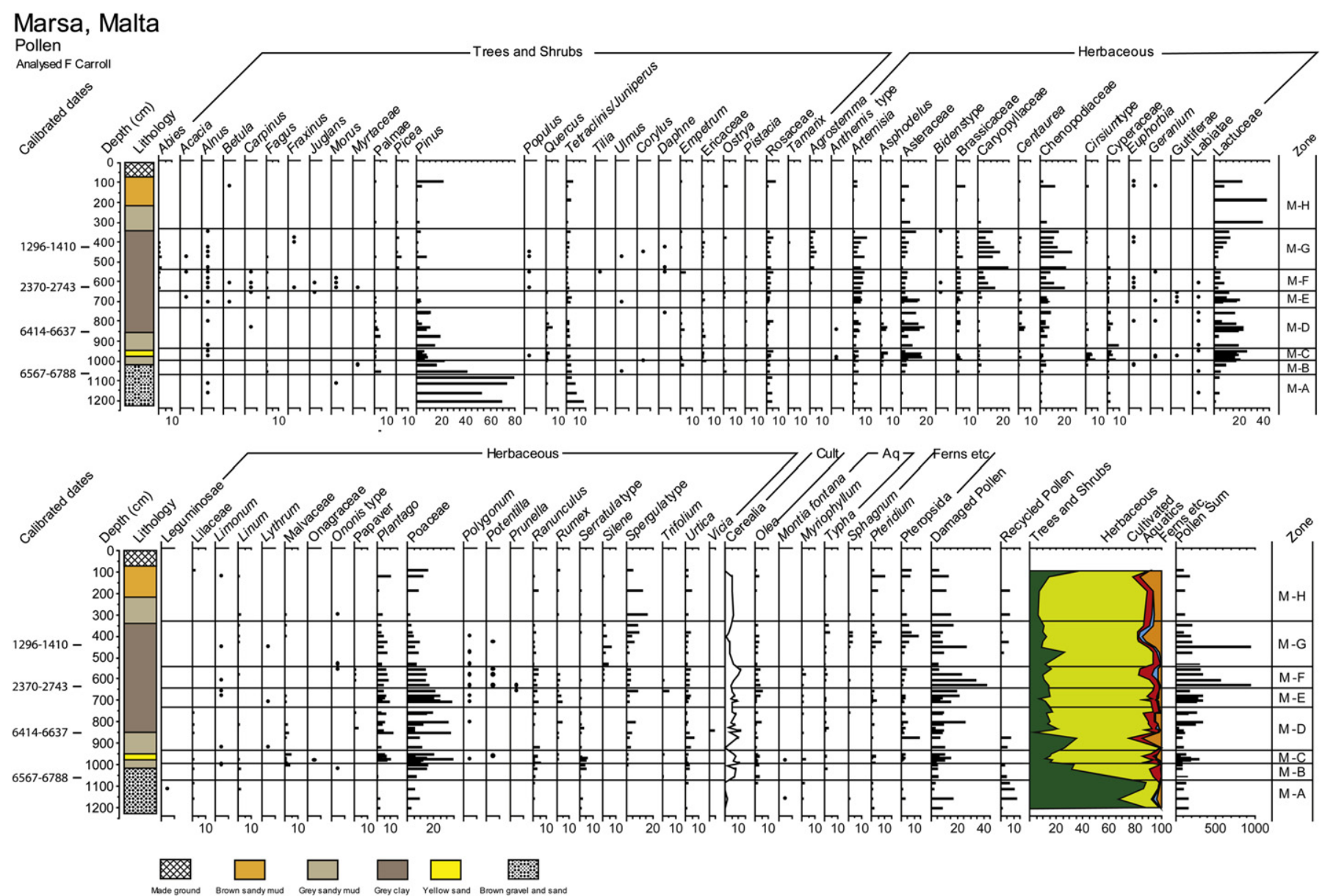

Fig. 5. Pollen analysis of the Marsa core.

record is intensely variable. Within the basal zones (C-A to C-D) there is an alternation of assemblages characterized by very high Centaurea and Chenopodiaceae, assemblages with high Lactucae and Asteraceae, and spectra with high Pinus and Gladiolus. Chenopodiaceae dominate zone C-E, while Lactucae and Asteraceae dominate the final zone (C-F). Most assemblages through the core are dominated by Psilate Algal Cysts, with very little marine material except in the topmost samples of zone C-F. Thermally mature material peaks in zones $\mathrm{C}-\mathrm{A}$ and $\mathrm{C}-\mathrm{E}$ and dominates the palynofacies in C-F.

\section{The Holocene vegetation history of the Maltese Islands}

The earliest palynological evidence in the Maltese Islands is from a core at Burmarrad which suggests that anthropogenic clearance had started before 7300 cal. BP, with fire and grazing leading to the development of pistachio scrub with areas of herbaceous vegetation, including Plantago lanceolata type, Rumex, Asphodelus and Thelygonum (Marriner et al., 2012: 61).

At Salina Bay, which is offshore from the Burmarrad site of Marriner et al. (2012), the dating framework is relatively secure. The earliest sediments recovered date from $\sim 6800 \mathrm{cal}$. BP (Fig. S1). At this point, high Plantago and Poaceae plus taxa such as Asphodelus and Urtica, suggest that grazing was an important part of the agricultural economy, but the Pistacia scrub noted by Marriner et al. (2012) had gone. The presence of cereal pollen would suggest that arable agriculture had become established. The decline in Plantago and rise in cereal pollen around 5800 cal. BP in zone S-B might be taken to suggest a change from mixed farming to a greater reliance on arable agriculture. This would equate broadly with the Mgarr phase of the Maltese Neolithic (Malone et al., 2009: 345). Marine sedimentation seems to have continued steadily at Salina Bay with an unchanging agricultural and steppeland landscape onshore through zone S-B until around $4300 \mathrm{cal}$. BP, which is close to the end of the Tarxien phase (Malone et al., 2009: 345). At this point cereal pollen declines and Plantago rises, perhaps reflecting less intensive agriculture with more grazing. The decline of the diversity of marine indicators, appearance of monospecific, bloom-type marine dinocyst assemblages and then rise of non-marine algal taxa near the top of zone S-B followed by non-marine algal-dominated assemblages and the appearance of high percentages of Polypodium and some Pteridium spores in zone S-C may suggest a change from open marine to prodelta environment at the core site, with the spores reaching the site by fluvial transport from eroding old forest soils in the catchment of the Burmarrad River. Cereal pollen reappears after a gap of around 400 years, during the early Bronze Age.

Unfortunately, the dating of the Marsa core, the longest sequence recovered in this study, is problematic, and any chronological interpretation must be made with considerable caution as a result of the large number of 'old' dates, which suggest the presence of much recycled carbon, and 'young' dates suggesting caving or other contamination. If the dates in stratigraphic order shown in Figs. 2, 5 and 6 are accepted as being broadly contemporaneous with the sediments in which they lie, then it can be 
Marsa, Malta

Non-Pollen Microfossils

Analysed F Carroll
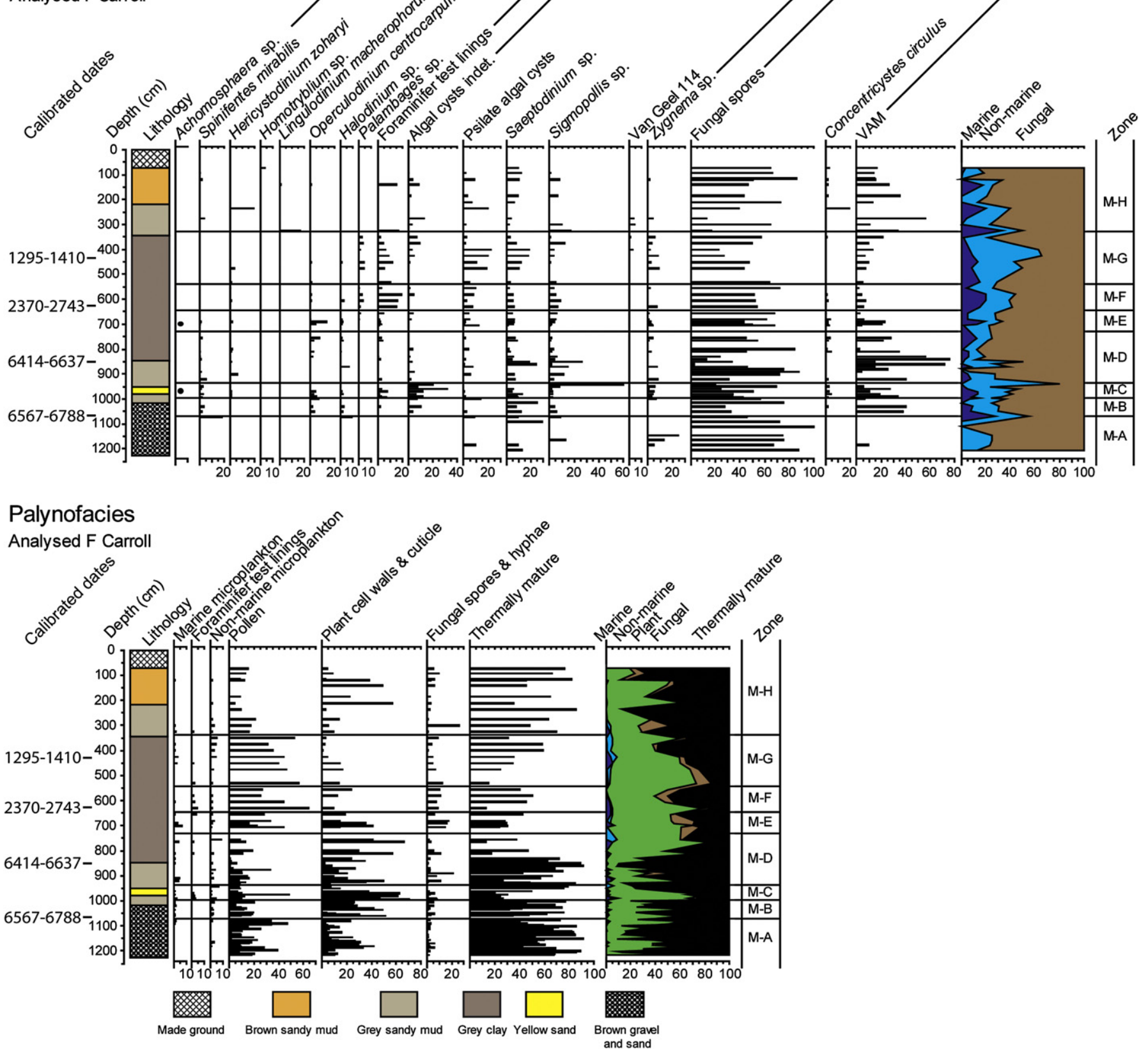

Fig. 6. Non-pollen microfossil and palynofacies analysis of the Marsa core.

tentatively suggested that the initiation of sedimentation at Marsa was ca 7000 cal. BP or a little after.

The basal sediments in the core are gravels and sandy clays of braided fluvial facies and they lack marine microfossils, so must predate the Holocene sea-level rise past this point. They lie at $7.8 \mathrm{~m}$ below Maltese Datum. In Italy, relative sea-level at 7000 cal. BP ranges from ca -5 to $-12 \mathrm{~m}$, with the closest calculated point on Sicily lying at $-11.7 \mathrm{~m}$ (Lambeck et al., 2011). The sedimentology of the gravels is consistent with them having accumulated very rapidly during a series of flash-floods. Three 'old' radiocarbon dates occur in the lower part of the core (Beta-203318, Beta-208959, Beta-203320). Teeth of the extinct Pleistocene vole Pitymys melitensis were recovered from $11.8 \mathrm{~m}$ (Fenech, 2009). Further, recycled pollen, Concentricystes circulus and VAMs are common in the lower half of the core (Fig. 5). VAMs are root symbionts of higher plants and thus common in soils and $C$. circulus is also derived from soils (Hunt, 1994). All of these testify to the admixture of sediment containing older carbon, as might be expected if soils were eroding catastrophically and ancient material was being redeposited. The extremely high values for magnetic susceptibility (Fig. 2) and the high counts for thermally mature material (Fig. 6) below $8 \mathrm{~m}$ are likely to reflect burning in the catchment. The pollen from the sandy clay units in the gravels (zone M-A, Fig. 3) is heavily dominated by Pinus, with some Tetraclinis/Juniperus, and some openground taxa suggesting at face-value rather open pine-sandarac gum/juniper woodland. Pinus is, however, a very high pollen 

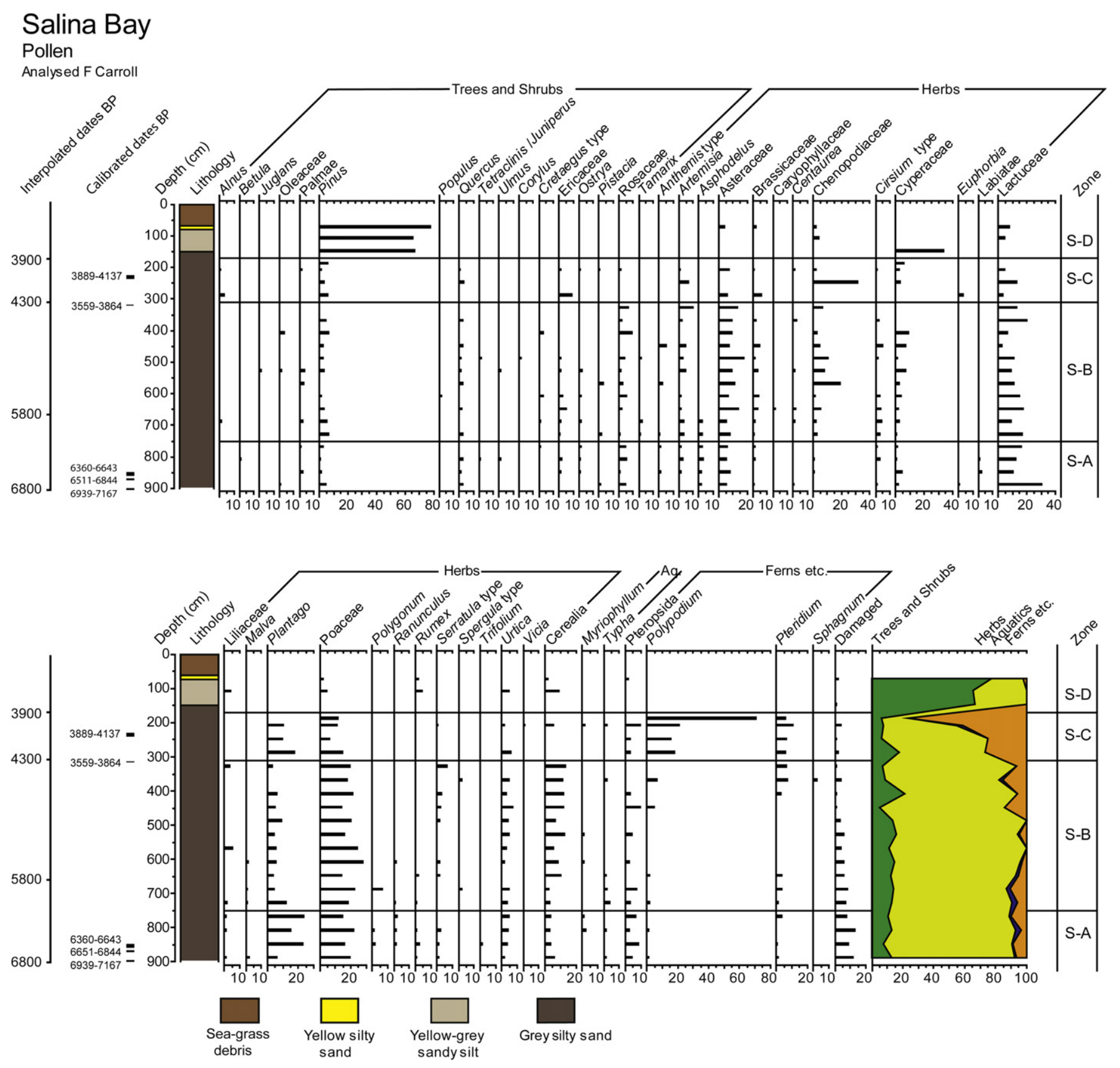

Fig. 7. Pollen analysis of the Salina Bay core.

producer, and moreover, is very taphonomically robust (Havinga, 1984) and thus pine pollen is often 'over-represented' in fluvial sediments (Hunt, 1994), so it is entirely possible that pine did not dominate the vegetation. It is also possible that some of the pollen in this zone was inherited from a possible soil cover and thus, to an extent, reflects pre-clearance vegetation, although fluorescence microscopy did not indicates a large recycled component. It can thus be suggested that the basal gravelly sediments accumulated very rapidly as a response to clearance and the contained pollen assemblages are perhaps in part inherited from eroding soils.

Features known as 'cart ruts' - ancient rutted trackways incised into the limestone bedrock from a former soil cover by carts or sledges (Mottershead et al., 2008, 2010) are widespread in the Maltese Islands. Their date has been a matter of contention for many years but it is clear that they were formed as the soil cover eroded away (Mottershead et al., 2008, 2010). The thick sediments of early Neolithic age at Marsa and at Burmarrad (Marriner et al., 2012), where $\sim 4 \mathrm{~m}$ of sediment accumulated in $\sim 500$ years, provide evidence for intense soil erosion at this time and thus might be used to suggest that the cart ruts may be, in part or whole, of Neolithic age.

The first marine indicators in the core lie close to the date of $5870 \pm 40$ bp (6567-6588, 6603-6610 and 6616-6788 cal. BP: Beta-200519) at $10.58-10.63 \mathrm{~m}$ in the core and thus $\sim 5.5 \mathrm{~m}$ below Maltese datum. Italian sea levels at $6500 \mathrm{cal}$. BP were between -3.7 and $-9.2 \mathrm{~m}$, with the nearest site on Sicily at $-8.1 \mathrm{~m}$ (Lambeck et al., 2011). If the dating of the core is accepted, this would suggest that the Marsa area has suffered a tectonic positive displacement of some $2 \mathrm{~m}$ since $6500 \mathrm{cal}$. BP. It is unlikely that this is a long-term trend as interglacial marine deposits are not found 
Salina Bay, Malta

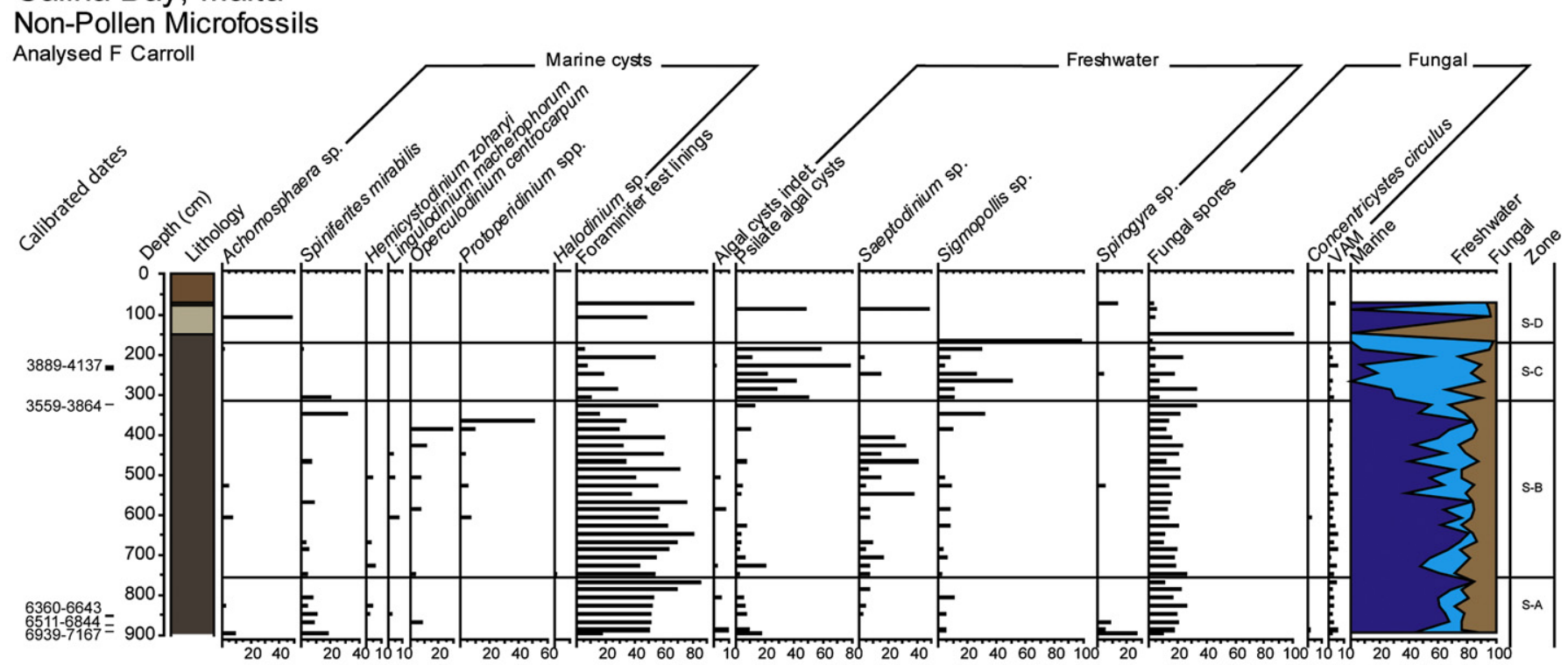

Palynofacies

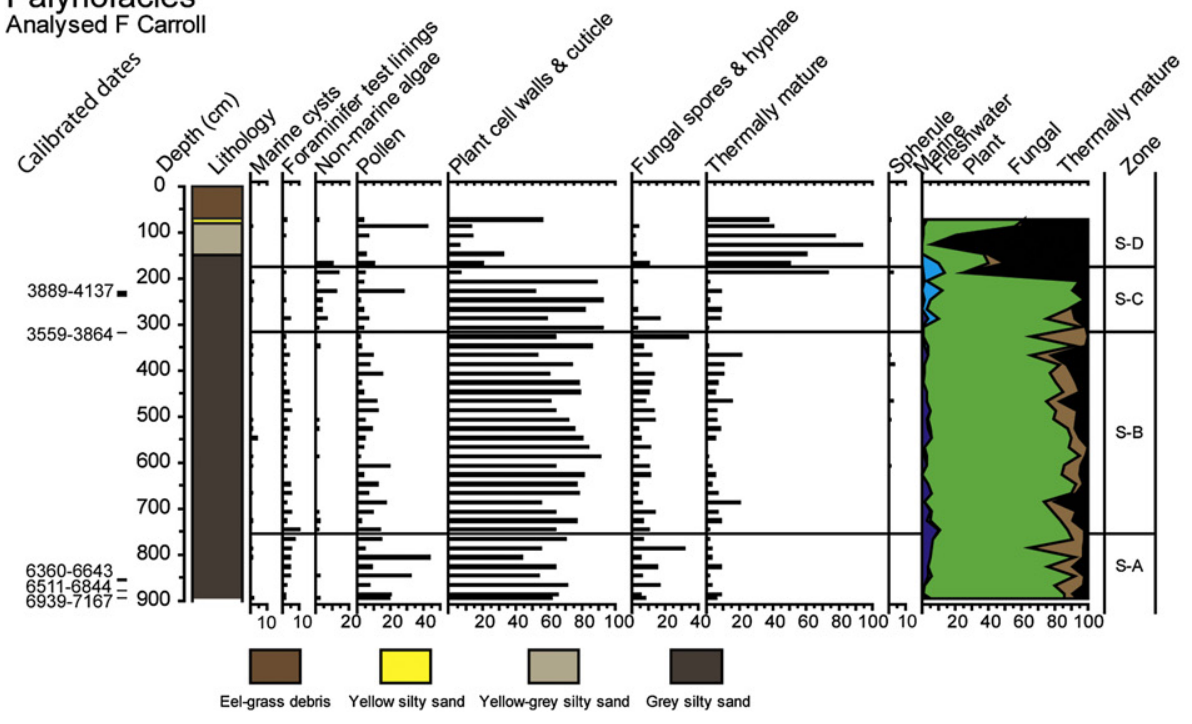

Fig. 8. Non-pollen microfossil and palynofacies analysis of the Salina Bay core.

onshore and thus are most probably submerged in the Maltese Islands (Hunt, 1997).

During zones M-B to M-D there is a decline in Pinus and Tetraclinis/Juniperus and a substantial rise in steppic taxa such as Poaceae, Artemisia, Plantago and Lactucae. Arable farming and arboriculture are suggested by high Cerealia and the consistent presence of Olea. Cultivation can perhaps be tentatively suggested, since the olive curve rises while the curve for Pinus and Tetraclinis/ Juniperus falls. It is a moot point whether the olive pollen initially reflects wild or cultivated trees - very early Neolithic domestication of olive is suggested from Israel (Galili et al., 1997) and Spain (Terral and Arnold-Simard, 1996) although the cultivation of wild varieties is also suggested from the Levant as late as the Iron Age (Kaniewski et al., 2009).

The appearance of broad-leaved taxa such as Quercus (deciduous and $Q$. ilex type) and Alnus, together with pollen comparable with the dwarf palm Chaemorops at this point could reflect longdistance transport of pollen from Sicily or other nearby continental areas, where these species are present throughout much of the Holocene (Ben Tiba and Rielle, 1982; Sadori and Narcisi, 2001; Sadori et al., 2008, 2011; Noti et al., 2009; Tinner et al., 2009). The appearance of far-travelled taxa may reflect diminishing local pollen rain with clearance, and the pollen-catchment characteristics must have changed at Marsa with rapidly-rising sea level, the flooding of the valley and the development of the ria - the expanding water-body would lead to a larger pollen catchment and more recruitment of far-travelled pollen. An alternative hypothesis would hold that the continuing presence of pollen of Pinus, Quercus, Olea, Juniperus/Tetraclinis and palm pollen in zones M-B to M-D could reflect the persistence of areas of scrub woodland in the Marsa catchment. It can, however, be suggested that clearance continued and that farming was firmly established at this site by ca 6600 cal. BP and continued thereafter throughout the Late Prehistoric.

If the dating can be substantiated, it would appear that there was earlier clearance and agricultural activity around Salina Bay and at Burmarrad, and thus that the progress of early agriculture showed spatial patterning, but this discrepancy may also reflect the 

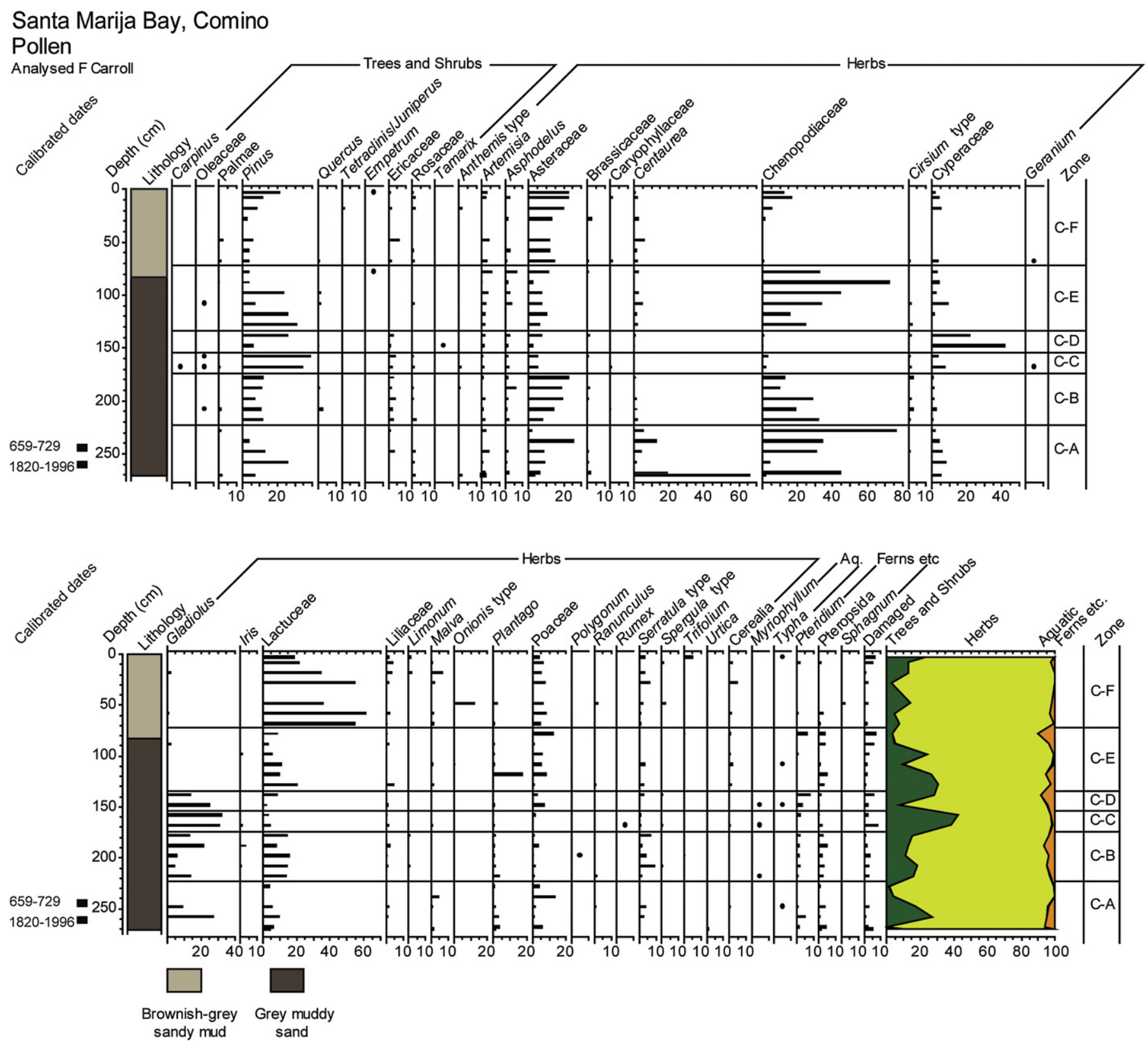

Fig. 9. Pollen analysis of the Comino Island core.

uncertain dating of the Marsa core. The presence of significant Pinus, Juniperus and Pistacia into the Tarxien period (maybe around 5000 cal. BP) at Tas-Silg (Hunt, in press) chimes with the suggestion of strong spatial patterning of early agriculture.

At Marsa, following the initial phase of rapid sedimentation, it is likely that there was a period of very slow deposition, during zones $\mathrm{M}-\mathrm{E}$ and M-F, or more probably that there were breaks in deposition of as much as three millennia. In spite of the changes in the herb pollen assemblages, there seems to have been very little environmental change, with continued evidence for arable agriculture in an open steppic landscape. There is a change in broadleaved tree taxa (all probably long-distance transported from Sicily and possibly other continental landmasses), with the decline of Quercus and appearance of Abies, Acacia, Fagus, Fraxinus, Juglans, Morus, Tilia. This probably reflects the general reorganization of forests in Southern Europe with desiccation events during the Mid-
Holocene (Mercuri et al., 2011), but also, in the case of Juglans, with introduction and propagation.

The rise in lead values at the base of zone M-G at Marsa may indicate the start of the global rise in lead values during the Roman Period (e.g. Grattan et al., 2007) and this would be consistent with the date of $2510 \pm 40 \mathrm{bp}(2370-2386$ and 2458-2743 cal. BP: Beta200517 ) at $6.28-6.33 \mathrm{~m}$. Cereal pollen percentages are lower in $\mathrm{M}-$ $\mathrm{G}$ than in previous zones and there is a decline in Poaceae and rises in Caryophyllaceae, Chenopodiaceae and Spergula type. This may reflect generally more degraded terrestrial environments, but may be also the result of the local dynamics of sedimentary systems and saltmarsh habitats at the back of the Grand Harbour. The basal date in the Comino core suggests an age close to the start of the Roman occupation of the Maltese Islands, and this is consistent with raised lead levels in zone C-A. It is clear that by this time the vegetation of Comino was already degraded steppe. 


\section{Santa Marija Bay, Comino \\ Non-pollen microfossils}

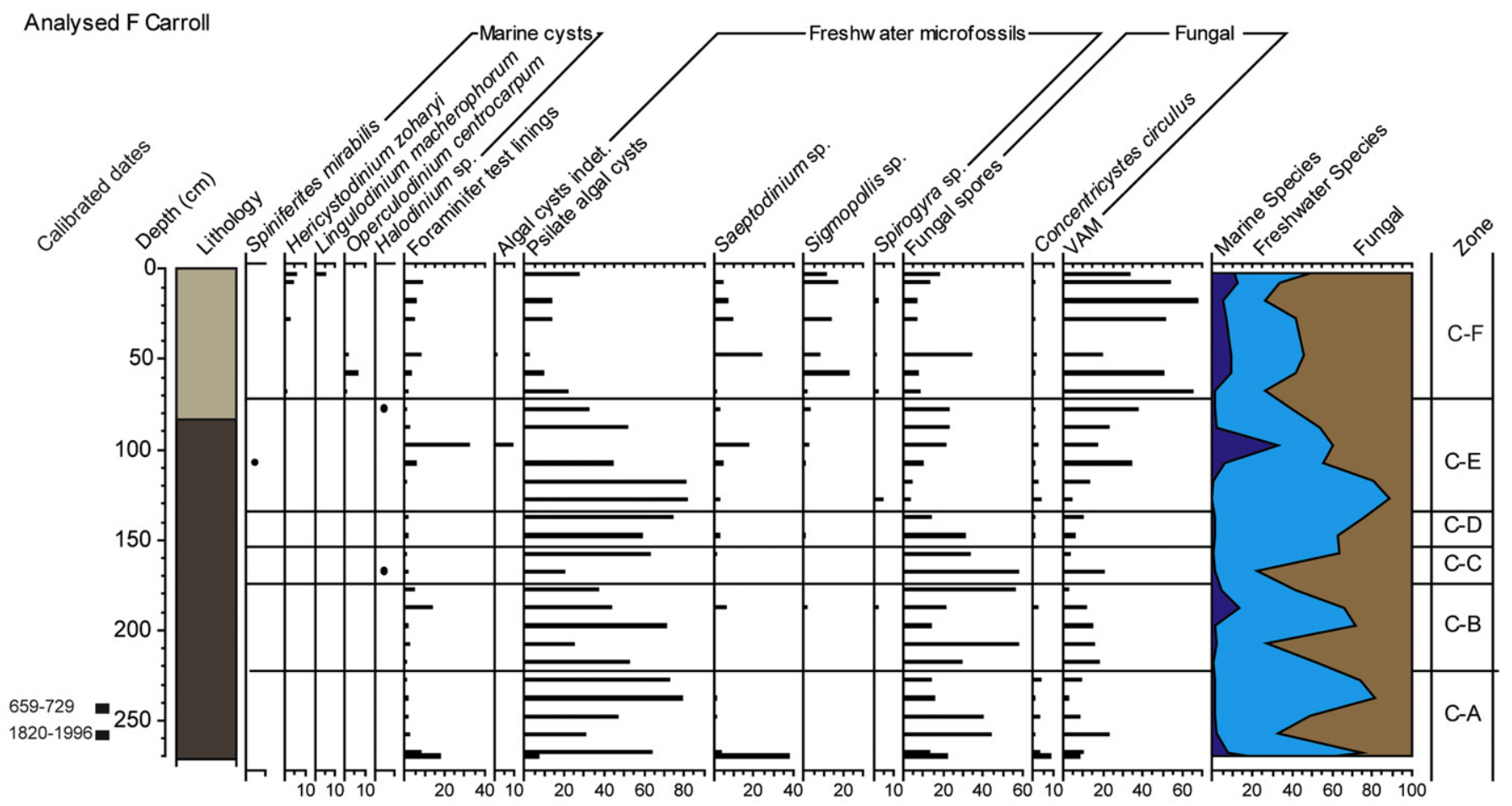

\section{Palynofacies}

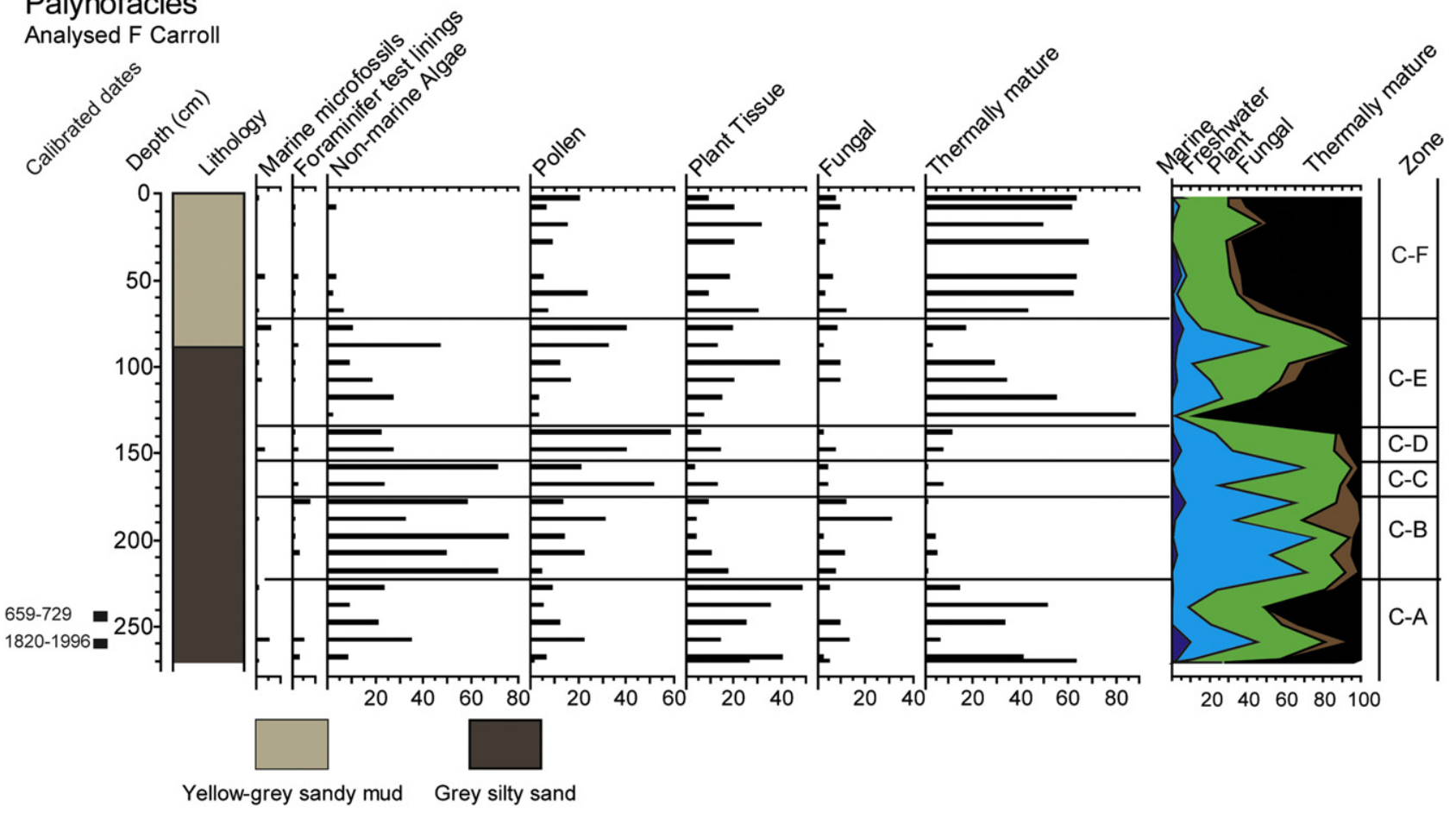

Fig. 10. Non-pollen microfossil and palynofacies analysis of the Comino Island core.

At Marsa, preservation of pollen in the uppermost zone (M-H) is poor, as is indicated by the very high percentages of the very corrosion-resistant Lactucae and the low taxonomic diversity of assemblages, but the pollen spectra are generally suggestive of degraded steppic environments with continued cereal cultivation. The Comino Island core provides a more detailed record of the last
1200 years, but the record appears to be marked strongly by shifting depositional environments, with coastal saltmarsh suggested by Chenopodiaceae peaks in C-A, C-B and C-E and a brief episode of freshwater marsh by a peak of Cyperaceae in zone C-D. The geophyte Gladiolus, typical of rocky places, is common in the lower part of the core, especially zones C-B to C-D, but is rare 
thereafter, whereas Cereals are present in zones C-E and C-F. It is tentatively suggested that the virtual disappearance of Gladiolus and appearance of cereals are the result of the establishment of fields in the valley behind Santa Marija Bay, possibly (as elsewhere in the Maltese Islands) during the seventeenth Century AD (Blouet, 1997). Very high Lactucae in zone C-F probably reflect poor conditions for the preservation of pollen, but the rise in Pinus at the end of this zone probably reflects the establishment of plantations on Malta. Likewise, Pinus rises at the end of zone $\mathrm{M}-\mathrm{H}$ at Marsa, just below the made ground of the 1860s. It is likely that zone S-D at Salina Bay is from a subrecent infilling of a former dredged channel, with the high Pinus in this zone reflecting the trees at Kennedy Grove or in older plantations at Bidnija and Wardija.

\section{Evidence for climate change}

The extremely strong evidence for anthropogenic impact through these records makes it extremely difficult to reconstruct climatic history. The pre-clearance vegetation of the islands appears to have been some form of fairly open pine-sandarac gum/ juniper-pistachio woodland, although the importance of pine may be taphonomically exaggerated in the pollen diagrams. This may be comparable climatically with similar vegetation in coastal Cyrenaica (Hunt et al., 2011a, 2011b) with mean annual rainfall of about
$400 \mathrm{~mm}$ per year, very similar to the mean rainfall recorded in the 20th Century in Malta (Chetcuti et al., 1992).

The maintenance of what was mostly rainfed cereal agriculture throughout most the period from $6800 \mathrm{cal}$. BP to the present day on Malta suggests no great disruptions by climate throughout this long period, except for the event at the end of the Tarxien Period around 4300 cal. BP, although it is clear from the small-scale traditional irrigation and water-storage systems still visible in the islands (Jones and Hunt, 1994) that farmers have long attempted to minimize climatic risk. Other than the event at 4300 cal. BP, evidence for the major environmental shocks caused by the aridification events seen in North Africa (e.g. Faust et al., 2004; Zielhofer et al., 2004) and in Southern Europe (e.g. Magny et al., 2011; Sadori et al., 2011) is not forthcoming in the palaeoecological record from Malta (Fig. 11).

Comparison with the Sicilian and Tunisian records is problematical after the Neolithic because of the considerable extent of deforestation in the Neolithic, which seems to have virtually eliminated all woody vegetation on Malta except for olives. The very low level of tree and shrub pollen after the Neolithic means that comparison with the tree pollen curves, which are often used as a climatic proxy (e.g. Magny et al., 2011), becomes impossible. This evidence for substantial human impact is significantly earlier than similar evidence elsewhere in the Western and Central Mediterranean (cf. Sadori, 2007).

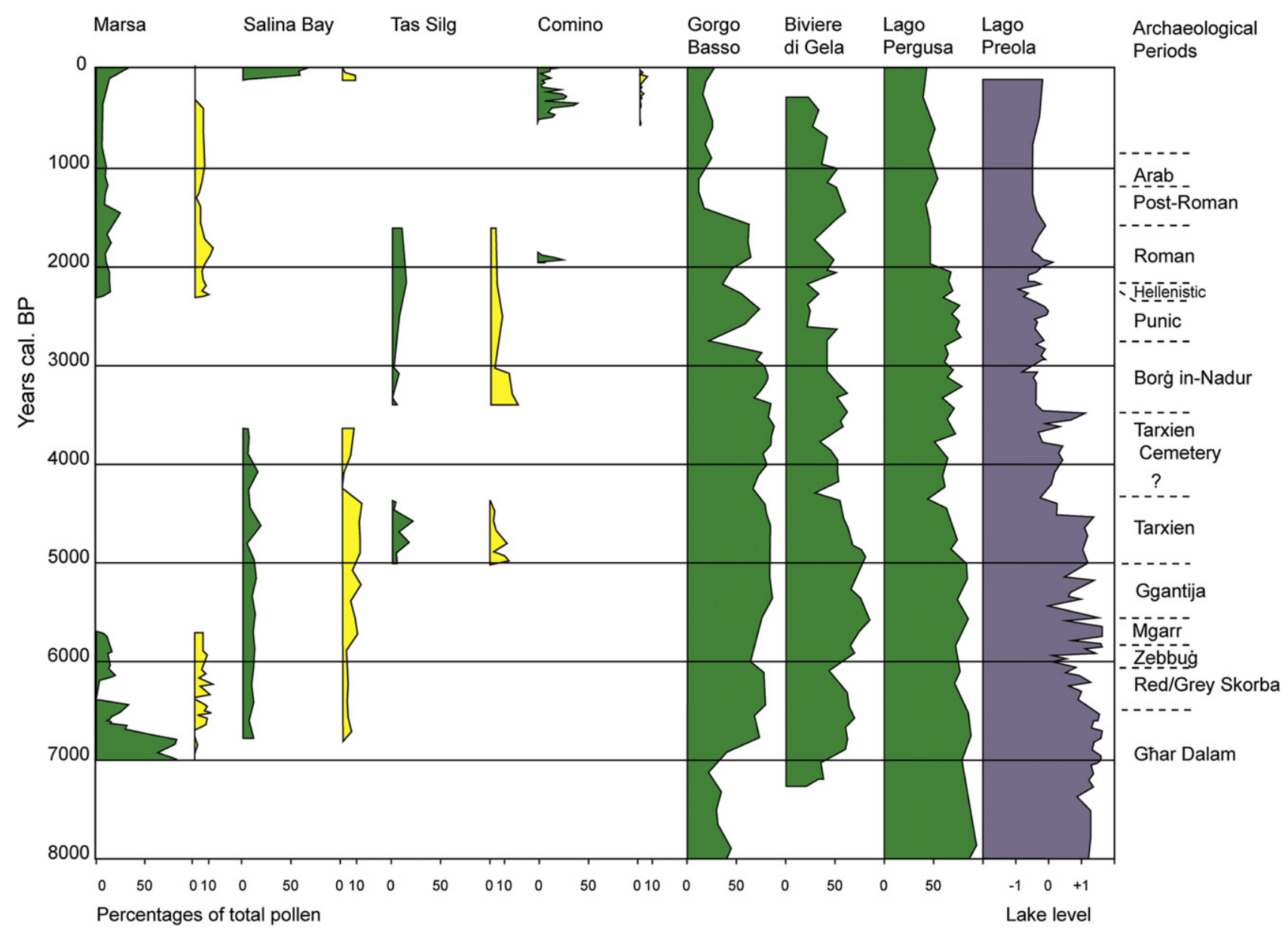

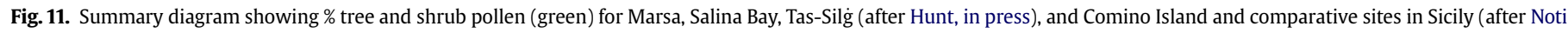

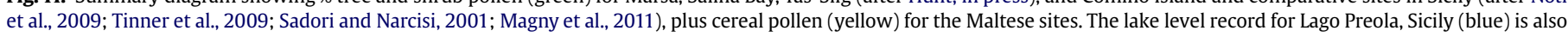

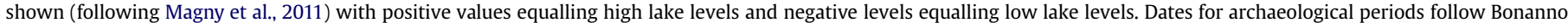

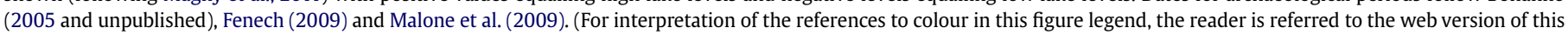
article.) 


\section{The first colonisation of the Maltese Islands}

Evidence, in any form, for the first colonisation of the Maltese Islands is difficult to come by, but the work of Zilhao (2001) suggests it could have happened any time after 8000 years ago. Zilhao's (2001) evidence is strongly consistent with the first agricultural colonists in the Western and Central Mediterranean dispersing by sea, so the channel between Sicily and Malta would not have been an insuperable barrier. The date of the first occupation of the Maltese Islands is widely placed around 7000 years ago (Trump, 1995-1996, 2002; Bonanno, 2003; Pace, 2004). This estimate is based upon archaeological findings from the early Neolithic Ghar Dalam cultural phase but without the benefit of modern radiocarbon dating [Trump's (1966) uncalibrated date of $6140 \pm 160$ bp (S-BM378) calibrates to a wide range between 6664 and $7415 \mathrm{cal}$. BP at $2 \sigma$.

Deforestation and the appearance of grazing indicators were apparent at Burmarrad by 7300 cal. BP (Marriner et al., 2012) and cereal cultivation was established by the start of the Salina Bay record around $6800 \mathrm{cal}$. BC. It is likely, therefore, that the first colonisation of the islands was some considerable time before this and most probably (Marriner et al., 2012) before 7500 cal. BP. It would appear that clearance had occurred at Marsa at the latest by ca 6500 cal. BP. The available evidence seems to suggest that the commencement of Neolithic agriculture was spatially variable, probably earlier in North Malta than on the dry limestone plateaux of southern Malta near Marsa and Tas-Silg.

\section{Agriculture in the Temple Period and its aftermath}

At Salina Bay, agricultural intensification and a switch from mixed farming to cereals seems to have occurred in the Mgarr Phase (Fig. 11), shortly before the first great Maltese temples were erected but long after sites that would become temples, such as the Xaghra (Brocktorff) Circle, had been initiated as funerary sites (Malone and Stoddart, 2009). Cereal-based agriculture seems to have persisted until $4300 \mathrm{cal}$. BP, close to the end of the last, Tarxien, phase of the Temple Period. At that point it would appear that arable agriculture declined dramatically. The rise of Plantago might suggest pastoralism, but it is difficult to conceive a regeneration flora in a suddenly-arid landscape where the woody vegetation had long been eliminated and it is possible that this reflects an abandoned landscape.

In the literature on Maltese prehistory, there are references to periods when the Islands were uninhabited, hypothetically attributed to environmental change. Trump (2002), for instance, alludes to the possibility that the Islands may have been depopulated at the end of the Temple period, citing the lack of archaeological evidence for immediate successors to the Temple peoples. Evans (1971) was also a supporter of 'dark periods' of depopulation. Pace (2004) also discusses the possibility of depopulation and highlights evidence, discovered by Temi Zammit, of a 'sterile' layer that was 'covered by a cremation cemetery at the Tarxien Temples' but contends that 'discontinuity, abandonment or even continuity cannot be easily illustrated archaeologically' (Pace, 2004: 37). More recently, signs of a lack of protein among the last people to be buried in the final phases of the Xaghra (Brocktorff) Circle on Gozo were suggested by Malone and Stoddart (2009) to be evidence of environmental stress which they suggest culminated in the collapse of the Temple Culture.

What seems to be clear from the Salina Bay record is that there is no compelling pollen evidence for dramatic environmental changes, but there does seem to be a sudden cessation of cereal pollen, perhaps signalling agricultural collapse. This event and the end of the Temple Culture are close in time to evidence for rapid aridification in Sicily and Tunisia (Fig. 11; Ben Tiba and Reille, 1982;
Sadori and Narcisi, 2001; Tinner et al., 2009; Noti et al., 2009; Magny et al., 2011). If regional aridification contributed to the collapse of the Temple Culture, then it may also have been severe enough to have suppressed woodland regeneration, or the Neolithic population of the Maltese Islands may have reduced woody vegetation to the extent that it could no longer regenerate. Whether the Maltese Islands were abandoned completely at this time requires further research.

\section{The Arab Period 'abandonment'}

A later period when the Islands have been considered to be unpopulated occurred during the Arab occupation (870-1090 AD). This break is often quoted in Maltese literature since it was first published in The Times of Malta on 5 August 1990 (Brincat, 1995), especially amongst internet postings, and now appears to have been accepted as part of the historical fabric of the Islands. AlHimyari's account was some hundreds of years after the end of the Arab period with the date of his writings open to speculation as being either 1494 or 1326-7 AD. Furthermore, his information was derived from several sources, not all of which can be verified (Brincat, 1995). A stronger case for a depopulated Malta for more than a century is made on the basis of a clear statement by a contemporary geographer, ibn Hauqal, who, a few years before $988 \mathrm{AD}$, stated categorically that Malta was inhabited only by wild donkeys and numerous sheep (Wettinger, 2011).

At Marsa the Arab period does not seem associated with any major change in vegetation, and cereal pollen persists (Fig. 11), although the sampling resolution is rather low. It is therefore suggested tentatively that this 'dark' period of Maltese prehistory and history, suggested by historians and linguistic scholars, could be the result of fractures in a patchy record caused by the nature of the processes of formation of historical and linguistic evidence. The apparent break in the record does not seem to be matched by palynological evidence for the abandonment of agriculture, as might be expected. The apparent continuity of agriculture from the palynological evidence would, rather, be more consistent with a continuity of population in the Maltese Islands. Higher-resolution palynological work is necessary to resolve this issue.

\section{Conclusions}

The palynological work reviewed and reported here suggests that an early Holocene woodland featuring pine and sandarac gum/juniper was first impacted by Neolithic colonists some time before 7500 cal. BP. Cereal agriculture was established by 6800 cal. BP and seems to have persisted, largely unbroken, in the Maltese Islands until modern times, apart for the dramatic disappearance of cereal pollen at the end of the Temple Period. Considerable differences between the earliest records suggest that early Neolithic agriculture was patchy in distribution. The start of the social progress which culminated in the Temple Period coincides with evidence for agricultural intensification and its end is broadly contemporaneous with what appears to be a collapse in cereal production, most probably caused by regional aridity around $4300 \mathrm{cal}$. BP. Although archaeological evidence for the Neolithic is relatively late in Malta, the evidence for substantial human impact there is earlier than similar evidence elsewhere in the Western and Central Mediterranean, attesting to the fragility of the early Holocene environment in the Maltese Islands. The Maltese 'cart ruts' quite probably relate to Neolithic soil erosion, which seems to have been very intense with early clearance. The findings here show no evidence supporting the 150 years hiatus in human occupation of the islands following the Arab invasion of $870 \mathrm{AD}$, claimed by historians and linguists. Higher resolution and 
better-dated studies would, however, be necessary to be able to dismiss this idea conclusively.

\section{Acknowledgements}

Grateful thanks for financial support are due to the Old Temple Foundation of Florida, USA, for coring and dating support on the Marsa core, and the ${ }^{14}$ Chrono Centre at Queen's University Belfast for further dating. We thank Edwin Lanfranco, Caroline Malone, Simon Stoddart, Nicholas Vella, Anne Jones for stimulating discussion and useful guidance, Katrin Fenech, John Corr and Garry Rushworth for assistance with coring, Katrin Fenech for securing material for radiocarbon dates on the Marsa core and Maarten Blaauw for help with clam modelling. This paper was completed while $\mathrm{COH}$ was on sabbatical leave at the McDonald Institute for Archaeological Research, Cambridge. He thanks Simon Stoddart and Caroline Malone for their hospitality and St John's College, Cambridge, for dining rights. We thank Neil Roberts and two anonymous referees for their constructive criticism.

\section{Appendix A. Supplementary data}

Supplementary data associated with this article can be found, in the online version, at http://dx.doi.org/10.1016/j.quascirev.2012. 07.010.

\section{References}

Ben Tiba, B., Rielle, M., 1982. Recherches pollenanalytiques dans les montagnes de Kouroumie (Tunisie septentrionale): premiers resultats. Ecologia Mediterranea 8 (4), 75-86.

Blaauw, M., 2010. Methods and code for 'classical' age-modelling of radiocarbon sequences. Quaternary Geochronology 5, 512-518.

Blouet, B., 1964. The Changing Landscape of Malta During the Rule of the Crusading Order of St John of Jerusalem. Unpublished Doctoral dissertation, University of Hull.

Blouet, B., 1997. The Story of Malta, sixth ed. Progress Press, Malta.

Bonanno, A., 2003. Malta: an Archaeological Paradise. MJ Publications, Valletta.

Bonanno, A., 2005. Malta Phoenician, Punic and Roman. Midsea Books, Malta.

Borg, J., 1990. The Public Gardens and Groves of Malta and Gozo, third ed. Media Centre Publications, Malta.

Bosence, D., Pedley, M., Rose, E., 1981. Field Guide to Mid-Tertiary Carbonate Facies of Malta. Palaeontological Association, London.

Bowen-Jones, H., Beeley, B.W., 1960. Malta before 1800 AD. In: Bowen-Jones, H. Dewdney, J.C., Fisher, W.B. (Eds.), Malta Background for Development. University of Durham, Durham.

Brincat, J.M., 1995. Malta 870-1054 Al-Himyari's Account and its Linguistic Implications. Said International Ltd, Valletta.

Cassar, L.F., Conrad, E., Schembri, P.J., 2008. The Maltese Archipelago. In: Vogiatzakis, I.N., Pungetti, G., Mannion, A.M. (Eds.), Mediterranean Island Landscapes: Natural and Cultural Approaches. Springer, Heidelberg, pp. $297-$ 322.

Chetcuti, D., Buhagiar, A., Schembri, P.J., Ventura, F., 1992. The Climate of the Maltese Islands: a Review. Malta University Press, Msida.

COHMAP Members, 1988. Climatic changes of the last 18,000 years, observations and model simulations. Science 241, 1043-1052.

Drescher-Schneider, R., de Beaulieu, J.-L., Magny, M., Walter-Simonnet, A.-V., Bossuet, G., Millet, L., Brugiapaglia, E., Drescher, A., 2007. Vegetation history, climate and human impact over the last 15,000 years at Lago dell'Accesa (Tuscany, Central Italy). Vegetation History and Archaeobotany 16, 279-299.

Evans, J.D., 1971. The Prehistoric Antiquities of the Maltese Islands. Athlone Press, London.

Faust, D., Zielhofer, C., Escudero, R.B., del Olmo, F.D., 2004. High-resolution fluvial record of Late Holocene geomorphic change in Northern Tunisia: climatic or human impact? Quaternary Science Reviews 23, 1757-1775.

Fenech, K., 2009. Human-Induced Changes in the Environment and Landscape of the Maltese Islands from the Neolithic to the 15th Century AD as Inferred from a Scientific Study of Sediments from Marsa, Malta. BAR International Series 1682. Oxford.

Frisia, S., Borsato, A., Mangini, A., Spötl, C., Madonia, G., Sauro, U., 2006. Holocene climate variability in Sicily from a discontinuous stalagmite record and the Mesolithic to Neolithic transition. Quaternary Research 66, 388-400.

Gale, S.J., Hoare, P.G., 1991. Quaternary Sediments. Belhaven, London.

Galili, E., Stanley, D.J., Sharvit, J., Weinstein-Evron, M., 1997. Evidence for earliest olive-oil production in submerged settlements off the Carmel Coast, Israel. Journal of Archaeological Science 24, 1141-1150.
Gilbertson, D.D., Hunt, C.O., 1996. Quaternary geomorphology and palaeoecology. In: Barker, G.W.W., Gilbertson, D.D., Jones, B., Mattingley, D.J. (Eds.), Farming the Desert: the UNESCO Libyan Valleys Survey. UNESCO, Paris, pp. 49-82.

Godwin, H., 1961. Report on a Pollen Sample from the Late Borg in-Nadur Cistern at Tal-Mejtin. Report on the Working of the Museum Department for the Year 1961. Malta, Department of Information.

Grattan, J.P., Gilbertson, D.D., Hunt, C.O., 2007. The local and global dimensions of metalliferous pollution derived from a reconstruction of an eight thousand year record of copper smelting and mining at a desert-mountain frontier in southern Jordan. Journal of Archaeological Science 34, 83-110.

Grove, A.T., Rackham, O., 2001. The Nature of the Mediterranean Europe: an Ecological History. Yale University Press, New Haven.

Havinga, A.J., 1984. A 20-year investigation into the differential corrosion susceptibility of pollen and spores in different soil types. Pollen et Spores 26, 541-558. Horowitz, A., 1992. Palynology of Arid Lands. Elsevier, Amsterdam.

Hunt, C.O., Coles, G.M., 1988. The application of palynofacies analysis to geoarchaeology. In: Slater, E.A., Tate, J.O. (Eds.), Science and Archaeology. BAR Series 196. Oxford, pp. 473-484.

Hunt, C.O., Schembri, P.J., 1999. Quaternary environments and biogeography of the Maltese Islands. In: Mifsud, A., Savona Ventura, C. (Eds.), Facets of Maltese Prehistory. Prehistoric Society of Malta, Valletta.

Hunt, C., Vella, N.C., 2004-2005. A view from the countryside: pollen from a field at Mistra Valley, Malta. Malta Archaeological Review 7, 57-65.

Hunt, C.O., Rushworth, G., Gilbertson, D.D., Mattingly, D.J., 2001. Romano-Libyan dryland animal husbandry and landscape: pollen and palynofacies analysis of coprolites from a farm in the Wadi el-Amud, Tripolitania. Journal of Archaeological Science 28, 351-363.

Hunt, C.O., Elrishi, H.A., Hassan, A.T., 2002. Reconnaissance investigation of the palynology of Holocene Wadi deposits in Cyrenaica, Libya. Libyan Studies 33, 1-

Hunt, C.O., Gilbertson, D.D., El-Rishi, H.A., 2007. An 8000-year history of landscape, climate and copper exploitation in the Middle East: the Wadi Faynan and the Wadi Dana National Reserve in southern Jordan. Journal of Archaeological Science 34, 1306-1338.

Hunt, C.O., Reynolds, T.G., el-Rishi, H.A., Buzian, A., Hill, E., Barker, G.W., 2011a. Resource pressure and environmental change on the North African littoral: epipalaeolithic to Roman gastropods from Cyrenaica, Libya. Quaternary International 244, 15-26.

Hunt, C.O., Brooks, I., Meneely, J., Brown, D., Buzaian, A., Barker, G., 2011b. The Cyrenaican Prehistory Project 2011: Late-Holocene environments and human activity from a cave fill in Cyrenaica, Libya. Libyan Studies 42, 77-87.

Hunt, C.O., 1985. Recent advances in pollen extraction techniques: a brief review. In: Fieller, N.R.J., Gilbertson, D.D., Ralph, N.G.A. (Eds.), Palaeobiological Investigations. British Archaeological Reports, International Series, vol. 266. Oxford, pp. 181-187.

Hunt, C.O., 1994. Palynomorph taphonomy in the fluvial environment: an example from the palaeolithic site at High Lodge, Mildenhall, UK. In: Davis, O.K. (Ed.), Aspects of Archaeological Palynology: Methodology and Applications. American Association of Stratigraphic Palynologists Contributions Series, vol. 29, pp. 115126.

Hunt, C.O., 1995. The natural landscape and its evolution. In: Barker, G. (Ed.), A Mediterranean Valley. Leicester University Press, Leicester, pp. 62-83.

Hunt, C.O., 1997. Quaternary deposits in the Maltese Islands: a microcosm of environmental change in Mediterranean Lands. GeoJournal 41 (2), 101-109.

Hunt, C.O., 2000. Pollen. In: Bonanno, A., Frendo, A.J. (Eds.), Excavations in Tas-Silg, Malta. Mediterranean Archaeology, vol. 13, pp. 111-114.

Hunt, C.O., Palynology of Some Archaeological Deposits from Tas-Silg. In: Bonnanno, A., Vella, N. (Eds.), Excavations at Tas-Silg, Malta, Conducted by the Department of Classics and Archaeology, University of Malta (1996-2005). Malta, Midsea Publications, in press.

Jones, A.M., Hunt, C.O., 1994. Walls, wells and water supply: aspects of the cultural landscape of Gozo, Maltese Islands. Landscape Issues 11, 24-29.

Kaniewski, D., Paulissen, E., Van Campo, E., Bakker, J., Van Lerberghe, K., Waelkens, M., 2009. Wild or cultivated Olea europaea L. in the eastern Mediterranean during the middle-late Holocene? A pollen-numerical approach. The Holocene 19, 1039-1047.

Kuper, R., Kropelin, S., 2006. Climate-controlled Holocene occupation in the Sahara: motor of Africa's evolution. Science 313, 803-807.

Lambeck, K., Antonioli, F., Anzidei, M., Ferranti, L., Leoni, G., Scicchitano, G., Silenzi, S., 2011. Sea level change along the Italian coast during the Holocene and projections for the future. Quaternary International 232, 250-257.

Magny, M., Miramont, C., Sivan, O., 2002. Assessment of the impact of climate and anthropogenic factors on Holocene Mediterranean vegetation in Europe on the basis of palaeohydrological records. Palaeography, Palaeoclimatology, Palaeoecology $186(1-2), 47-59$.

Magny, M., Vannière, B., Calo, C., Millet, L., Leroux, A., Peyron, O., Zanchetta, G., La Mantia, T., Tinner, W., 2011. Holocene hydrological changes in south-western Mediterranean as recorded by lake-level fluctuations at Lago Preola, a coastal lake in southern Sicily, Italy. Quaternary Science Reviews 30, 2459-2475.

Magri, D., Sadori, L., 1999. Late Pleistocene and Holocene pollen stratigraphy at Lago di Vico, central Italy. Vegetation History and Archaeobotany 8, 247-260.

Magri, D., 1999. Late Quaternary vegetation history at Lagaccione, near Lago di Bolsena, Central Italy. Review of Palaeobotany and Palynology 106, 171-208.

Malone, C., Stoddart, S., 2009. Conclusions. In: Malone, C., Stoddart, S., Bonanno, A., Trump, D. (Eds.), Mortuary Customs in Prehistoric Malta. Excavations at the 
Brocktorff Circle at Xaghra 1987-1994. McDonald Institute Monographs, Cambridge, pp. 361-384.

Malone, C., Stoddart, S., Cook, G., 2009. Dating Maltese prehistory. In: Malone, C., Stoddart, S., Bonanno, A., Trump, D. (Eds.), Mortuary Customs in Prehistoric Malta. Excavations at the Brocktorff Circle at Xaghra 1987-1994. McDonald Institute Monographs, Cambridge, pp. 341-346.

Marquer, L., Pomel, S., Abichou, A., Schulz, E., Kaniewski, D., Van Campo, E., 2008. Late Holocene high resolution palaeoclimatic reconstruction inferred from Sebkha Mhabeul, southeast Tunisia. Quaternary Research 70, 240-250.

Marriner, N., Gambin, T., Djmali, M., Morhange, C., Spiteri, M., 2012. Geoarchaeology of the Burmarrad ria and early Holocene human impacts in western Malta. Palaeogeography, Palaeoclimatology, Palaeoecology 339-341, 52-65.

MEPA, 2006. State of the Environment Report 2005, Government of Malta, Valletta.

Mercuri, A.M., Sadori, L., Uzquiano Ollero, P., 2011. Mediterranean and north-African cultural adaptations to mid-Holocene environmental and climatic changes. The Holocene 21 (1), 189-206.

Mercuri, A.M., 2008a. Plant exploitation and ethnopalynological evidence from the Wadi Teshuinat area (Tadrart Acacus, Libyan Sahara). Journal of Archaeological Science 35 (6), 1619-1642.

Mercuri, A.M., 2008b. Human influence, plant landscape evolution and climate inferences from the archaeobotanical records of the Wadi Teshuinat area (Libyan Sahara). Journal of Arid Environments 72, 1950-1967.

Mottershead, D., Pearson, A., Schaefer, M., 2008. The cart-ruts of Malta: an applied geomorphology approach. Antiquity 82 (318), 1065-1079.

Mottershead, D., Farres, P., Pearson, A., 2010. The changing Maltese soil environment: evidence from the ancient cart tracks at San Pawl Tat-Targa, Naxxar. In: Smith, B.J., Gomez-Heras, M., Viles, H.A., Cassar, J. (Eds.), Limestone in the Built Environment: Present-Day Challenges for the Preservation of the Past. Geological Society, London, Special Publications 331, pp. 219-229.

National Statistics Office, 2010. Demographic Review 2009. National Statistics Office, Vallletta, Malta.

Noti, R., van Leeuwen, J.F.N., Colombaroli, D., Vescovi, E., Pasta, S., La Mantia, T., Tinner, W., 2009. Mid- and late-Holocene vegetation and fire history at Biviere di Gela, a coastal lake in southern Sicily, Italy. Vegetation History and Archaeobotany $18,371-387$.

Ouda, B., Zouari, K., Ouzedou, H.B., Chkir, N., Causse, C., 1998. Nouvelles donnés paléonvironmentales pour le Quaternaire récent en Tunisie Central (basin de Maknassy). Comptes Rendus de l'Academie des Sciences, Paris, Sciences de la terre et des planètes $326,855-861$.

Pace, A., 2004. Malta during prehistory: a overview. In: Gambin, K. (Ed.), The Development of Malta from an Islands People to an Island Nation. Midsea Books, Malta.

Paskoff, R., Sanlaville, P., 1978. Observations géomorphologiques sur les côtes de l'archipel maltais. Zeitschrift für Geomorphologie 22, 310-328.

Pedley, M., Clarke, M.H., Galea, P., 2002. Limestone Isles in a Crystal Sea. Enterprises Group PEG Ltd, San Gwann, Malta.

Ramrath, A., Sadori, L., Negendank, J.F.W., 2000. Sediments from Lago di Mezzano, central Italy: record of Lateglacial/Holocene climatic variations and anthropogenic impact. The Holocene 10 (1), 87-95.

Roberts, N., Stevenson, T., Davis, B., Cheddadi, R., Brewster, S., Rosen, A., 2004. Holocene climate, environment and cultural change in the circummediterranean region. In: Battarbee, R.W., Gasse, F., Stickley, C.E. (Eds.), Past Climate Variability Through Europe and Africa. Springer, Dordrecht, pp. 343362.

Roberts, N., Brayshay, D., Kuzucuoglu, C., Sadori, L., 2011a. The mid-Holocene climatic transition in the Mediterranean: causes and consequences. The Holocene $21,3-13$.

Roberts, N., Eastwood, W., Kuzucuoğlu, C., Fiorentino, G., Caracuta, V., 2011b. Climatic, vegetation and cultural change in the eastern Mediterranean during the mid-Holocene environmental transition. The Holocene 21 (1), 147-162.
Sadori, L., Narcisi, B., 2001. The postglacial record of environmental history from Lago di Pergusa, Sicily. The Holocene 116, 655-670.

Sadori, L., Zanchetta, G., Giardini, M., 2008. Last Glacial to Holocene palaeoenvironmental evolution at Lago di Pergusa (Sicily, Southern Italy) as inferred by pollen, microcharcoal, and stable isotopes. Quaternary International $181,4-14$.

Sadori, L., Jahns, S., Peyron, O., 2011. Mid-Holocene vegetation history of the central Mediterranean. The Holocene 21, 117-129.

Sadori, L., 2007. Pollen Records, Postglacial. Southern Europe. In: Encyclopedia of Quaternary Sciences. Elsevier, pp. 2763-2773.

Schembri, P.J., Lanfranco, E., 1993. Development and the natural environment in the Maltese Islands. In: Lockhart, D.G., Drakakis-Smith, D., Schembri, J. (Eds.), The Development Process in Small Island States. Routledge, London, pp. 247-266.

Schembri, P., Pedley, M., Hunt, C., Stoddart, S., 2009. The environment of Malta and Gozo and of the Xaghra Circle. In: Malone, C., Stoddart, S., Bonanno, A. Trump, D. (Eds.), Mortuary Customs in Prehistoric Malta. Cambridge University Press, Cambridge, pp. 17-39.

Schembri, P.J., 1995. Diversity and conservation of the non-marine molluscs of the Maltese Islands. In: van Bruggen, A.C., Wells, S.M., Kemperman, T.C.M. (Eds.), Biodiversity and Conservation of the Mollusca. Backhuys, Leiden, pp. 217-222.

Schembri, P.J., 1997. The Maltese Islands: climate, vegetation and landscape. GeoJournal 41 (2), 115-125.

Terral, J.-F., Arnold-Simard, G., 1996. Beginnings of olive cultivation in eastern Spain in relation to Holocene bioclimatic changes. Quaternary Research 46, 176-185.

Tinner, W., van Leeuwen, J.F.N., Colombaroli, D., Vescovi, E., van der Knaap, W.O. Henne, P.D., Pasta, S., D’Angelo, S., La Mantia, T., 2009. Holocene environmental and climatic changes at Gorgo Basso, a coastal lake in southern Sicily, Italy. Quaternary Science Reviews 28, 1498-1510.

Trechmann, C.T., 1938. Quaternary conditions in Malta. Geological Magazine 75, $1-$ 26.

Trump, D.H., 1966. Skorba. University Press, Oxford.

Trump, D., 1995-1996. Radiocarbon dates from Malta. Journal of the Accordia Research Institute 6, 173-177.

Trump, D., 2002. Malta: Prehistory and Temples. Midsea Books Ltd, Malta.

Tyson, R.V., 1995. Sedimentary Organic Matter. Chapman and Hall, London.

Vella, S., 2001. Soil information in the Maltese Islands. In: Zdruli, P., Steduto, P. Montanarella, L. (Eds.), Soil Resources of Southern and Eastern Mediterranean. Options Méditerranéennes, Série B 34, pp. 171-191.

Watrin, J., Lézine, A.M., Hély, C., 2009. Plant migration and plant communities at the time of the "green Sahara". Comptes Rendus Geoscience 341, 656-670.

Watts, W.A., Allen, J.R.M., Huntley, B., Fritz, S.C., 1996. Vegetation history and climate of the last 15,000 years at Laghi di Monticchio, Southern Italy. Quaternary Science Reviews 15, 113-132.

Wettinger, G., 2011. Malta in the high middle ages. Melita Historica [Malta] 15 (4), 367-390.

White, K., 2000. Review of land degradation in mediterranean environments of the world: nature and extent, causes and solutions. Applied Geography 20, 83-93.

Zielhofer, C., Faust, D., Diaz del Olmo, F., Baena, R., 2002. Sedimentation and soil formation phases in the Ghardimaou Basin Northern Tunisia during the Holocene. Quaternary International 93-94, 109-125.

Zielhofer, C., Faust, D., Baena Escudero, R., Diaz del Olmo, F., Kadereit, A Moldenhauer, K.-M., Porras, A., 2004. Centennial-scale late-Pleistocene to midHolocene synthetic profile of the Medjerda Valley, northern Tunisia. The Holocene 14 (6), 851-861.

Zielhofer, C., Faust, D., Linstädter, J., 2008. Late Pleistocene and Holocene alluvial archives in the Southwestern Mediterranean: changes in fluvial dynamics and past human response. Quaternary International 181, 39-54.

Zilhao, J., 2001. Radiocarbon evidence for maritime pioneer colonization at the origins of farming in West mediterranean Europe. Proceedings of the National Academy of Sciences 98 (24), 14180-14185. 